\title{
Det jødiske folk og folkelighedsbegrebet i 1814-krøniken
}

\author{
Kim Arne Pedersen
}

Artiklen omhandler baggrunden for og lanceringen af folkelighedsbegrebet i Kort Begreb af Verdens Krønike betragtet $i$ Sammenhang fra 1814. Der redegøres for begrebets snævre sammenhæng med Grundtvigs statspolitiske anskuelser, teologi og historiesyn, og herunder forbindelsen til syvmenighedstanken. Undersøgelsen viser som tidligere forskning i andre værker den tydelige inspiration fra J.G. Herders ideer om national egenart og Fichtes idé om "Normalfolket", men gør det endvidere klart, at krønikens synpunkter fremsættes med klar adresse til en række samtidige holdninger til og diskussioner om jødedommen. Grundtvig var bekendt med store dele af tidens gammeltestamentlige forskning, der gik hånd i hånd med en negativ indstilling til jøderne i samfundet. I forhold hertil udgør tankerne om folkelighedens oprindelse i jødedommen i oldtiden i 1814-krøniken et bevidst og selvstændigt alternativ, der overraskende nok viser sig at udgøre en væsentlig forudsætning for Grundtvigs senere tanker om den opinionsstyrede kongemagt. Artiklen påviser derved en sammenhæng i den yngre Grundtvigs tænkning, der ikke tidligere har været belyst i forskningen, til trods for at den på mange måder er forudsætningen for at forstå udviklingen af såvel hans politiske idealer som den livs- og verdensanskuelse, der fra 1830'erne fandt et nogenlunde stabilt udtryk i forfatterskabet.

\section{Forskningen i 1814-krøniken}

Grundtvigs tre tidlige verdenskrøniker fra henholdsvis 1812, 1814 og 1817 såvel som hovedværket Haandbog $i$ Verdens-Historien 1833-1843 spiller en grundlæggende rolle i forfatterskabet og har påkaldt sig forskningens 
interesse fra efterkrigstiden og frem til i dag. Det mindst udforskede af de nævnte værker, Kort Begreb af Verdens Krønike betragtet i Sammenhang fra 1814 ( $V K$ 1814), fylder rundt i år, og jubilæet bør markeres på grund af værkets betydning for tilblivelsen af Grundtvigs forfatterskab. $V K 1814$ er blevet til under inspiration fra luthersk historieskrivning og samfundstænkning, men er også formet af det deuteronomistiske historiesyn i Det Gamle Testamente. Hertil kommer Grundtvigs egenartede indoptagelse af nationsbegrebet og en organisk udviklingsforståelse, som var stærkt præget af Goethe-tidens tyske kultur. ${ }^{1}$

Inden for forskningen findes der en række undersøgelser af $V K$ 1814, der er gennemført som led i fremstillinger med et andet sigte. Desuden foreligger der en række studier i tematiske sammenhænge i værket. Ud over afsnittet om VK 1814 i Flemming Lundgreen-Nielsens disputats, Det handlende ord 1980, er der imidlertid ingen arbejder, der har forsøgt at fremlægge et helhedsbillede af krøniken. Endvidere er Grundtvigs kilder til værket - til trods for, at han som i Haandbog $i$ Verdens-Historien gør rede for sit materiale i fodnoter - til dato ikke blevet underkastet en fyldestgørende undersøgelse. ${ }^{2}$

$V K 1814$ har i Grundtvigforskningen været behandlet ud fra en antropologisk-filosofisk og teologisk interesse (Høirup 1949, 93 ff.; Sølvbjerg 1982, 46 ff.; Christensen 1998, 118 ff.), en litteraturhistorisk tilgang (Toldberg 1950, 16 ff.) og ud fra en historiografisk vinkel (Michelsen 1954, 40 ff.; Aarnes 1961, 142 ff.; Vind 1999, 119 ff.). Hertil kommer undersøgelser med en litterær, teksthistorisk helhedsbetragtning (Lundgreen-Nielsen 1980, 617 ff.) og et henholdsvis eksistentielt og værkanalytisk udviklingshistorisk perspektiv (Elbek 1973, 22; Holm 2001, 19 f.; Auken 2005, 205 ff.). De teologiske undersøgelser har lagt vægt på skabelsesteologien, billedet af det gammeltestamentlige hyrdeliv og bibelsynet (Grell 1980, 32 ff.; 198896 ff.; Thodberg 1998, 66; Mikkelsen 1994, 123 ff.; Rosendal

${ }^{1}$ Til Goethetiden (ca. 1770-1830) og organismetanken se Øhrgaard 1994, 161 ff. og $166 \mathrm{f}$.

${ }^{2}$ Lundgreen-Nielsen skriver præcist, at Grundtvig "I stedet for" 1812-krønikens "mange hastigt og kategorisk udtrykte domme" i $V K 1814$ "har givet sig til at slå tingene ordentlig efter hos specialister og til at formulere sig mere nuanceret og begrundende" (Lundgreen-Nielsen 1980, 620). 
2006, 81 ff.; Høgenhaven 2011, 56). ${ }^{3}$ Mikkelsens undersøgelse udmærker sig trods sin koncentration om Grundtvigs senere salmedigtning ved bevidstheden om, at Grundtvig tænker i samfundsformer og næringsveje i 1814-krøniken.

Dette perspektiv udbygges i nærværende artikels undersøgelse af Grundtvigs lancering af folkelighedsbegrebet. Samtidig fremdrages begrebets sammenhæng med syvmenighedstanken og Grundtvigs opfattelse af jødedommen.

\section{Eksisterende tolkninger af folkelighedsbegrebet}

Inden for Grundtvigforskningen har K.E. Bugge i Skolen for Livet. Studier over N.F.S. Grundtvigs padagogiske tanker 1965 ført folkelighedsbegrebets opkomst tilbage til 1817-krøniken. Bugge gør opmærksom på, at forstadier til begrebet i dette værk optræder i en politisk sammenhæng. ${ }^{4}$ Han anslår, at Grundtvigs kilder er en række tyske forlæg, hvor begrebet bruges synonymt med "Nationalität" (Bugge 1965, 202). Også Flemming Lundgreen-Nielsen har betonet sammenhængen med nationalitetstanken. I et kapitel om Grundtvig og danskhed i Dansk Identitetshistorie gør han rede for, at det "I lyset af folkehøjskolernes senere udbredte brug af det folkelige er (...) vigtigt at fastholde, at ordet hos Grundtvig oprindeligt er hans personlige purisme for 'nationalitet"' (Lundgreen-Nielsen 1992, 97).

Alle disse udlægninger kan genfindes i Ordbog over Det Danske Sprog, hvor "Folkelighed" bestemmes som "nationalitet" og "folkelig" og som det

3 Christian Thodberg tolker virkningen af Grundtvigs forhold til den gamle pagts bøger sådan, at den danske kirkelige tradition i dag har et mere "fri $[\mathrm{t}]$ og naturlig[t]" forhold til Det Gamle Testamente, end det er tilfældet andre steder. Grundtvig havde ikke brug for at "tage Ny Testamente på forskud" og "med vold og magt at tolke hvert ord i Gammel Testamente som handlende om Kristus" (Thodberg 1998, 66). Jesper Høgenhaven er mere præcis, når han i stedet peger på Grundtvigs dybe afhængighed af den kirkelige traditions brug af Det Gamle Testamente. I Grundtvigs tidlige forfatterskab møder man ifølge Høgenhaven en skribent, "der er optaget af at forsvare de gammeltestamentlige teksters karakter af Kristus-profetier i overensstemmelse med kirkelig tradition og i modsætning til historisk-kritisk eksegese" (Høgenhaven 2011, 56).

${ }^{4}$ Grundtvig arbejder med begrebet i forbindelse med "repræsentative Forfatninger, Trykkefrihed og sligt" (VK 1817, XXVIII). 
“som passer for ell. er karakteristisk for det enkelte folk". Under opslaget på substantivet "Folk" forekommer imidlertid endnu en betydning, som er interessant i forbindelse med Grundtvig. Ordet kan også betyde: "hovedmængden af den enkelte nations medlemmer, udgørende en helhed indadtil som statens borgere, undersaatter i forhold til statsoverhovedet", idet "Folk" da benyttes i betydningen en "samling personer, der indtager samme stilling i forhold til et bestemt formaal ell. en bestemt person".

Denne indholdsbestemmelse af ordet "Folk" gør det muligt at bruge ordet i sammenhæng med den kontraktordning, som den norske historiker Jens Arup Seip (1913-1992) har kaldt "den opinionsstyrede enevælde". Seip påviser, at den opinionsstyrede enevældes tanke om den enevældige konges forpligtelse til at følge den folkevilje, som manifesterer sig i den borgerlige offentligheds opfattelse af det samfundsgavnlige, også har præget Grundtvig. Grundtvig har bl.a. givet sin tilslutning til denne model i digtet "Konge-Haand og Folke-Stemme" fra 1839. Her skildrer han i strofe 4, hvordan den danske kongelov fra 1665 frigjorde kongen ved at løse ham af håndfæstningen, og citerer indirekte Kongeloven ved at gøre rede for, at denne frigørelse gennemførtes ud af "Kiærlighed" (PS VI, 233). På tilsvarende vis skal kongen nu forløse folkestemmen, så den bliver i stand til at ytre sig frit. Etnologen Tine Damsholt (1961-) har videreført Seips iagttagelser, idet hun har trukket en linje fra Grundtvig til Hal Kochs (19041963) demokratibegreb, hvor samtalen står centralt. Denne linje danner også baggrund for Ove Korsgaards (1942-) tolkning af Hal Koch i Kampen om Lyset, hvor det grundtvigske folkelighedsbegreb kontrasteres med den anglo-amerikanske idé om civilsamfundet. Korsgaard kan konstatere, at folkelighedsbegrebet i Danmark til dels har forhindret, at begrebet "det civile samfund” er slået igennem (Korsgaard 1997, 120). Alligevel er der ikke mindst i kraft af Hal Koch sket en glidning i betydningen af ordet "folkelig" fra "national" til "demokratisk", hvor visse elementer fra den amerikanske republikanske tradition er blevet indoptaget i dansk tænkning. Det gælder især forestillingen om medborgerlighed (Korsgaard 1997, 122), der betoner borgerens individuelle, moralske ansvar for samfundet. Hvor Grundtvig henviser til folkets egenart, når det gælder politisk styreform, "betoner Hal Koch et humanistisk perspektiv" (Korsgaard 1997, 355) og frigør således det grundtvigske samtalebegreb fra af dets oprindelige nationale sammenhæng. 
For Hal Koch behøvede folkestyret således ikke at have rod i en fælles national identitet. Hans synspunkt var, at der uanset forskellige kulturer og livsformer kan etableres et demokrati, hvis borgeren vælger rollen som medborger (Korsgaard 1997, 355). Korsgaards tolkning af Hal Koch bærer præg af, at den er blevet til i globaliseringens tidsalder, hvor bevidstheden om menneskehedens indbyrdes afhængighed præger debatten, og hvor individets myndiggørelse er en forudsætning for demokratiet.

Alle disse forskellige tolkninger betoner vigtige sider af Grundtvigs begreb om folkelighed, men er ikke opmærksomme på, som det vil fremgå af nærværende artikels analyse af $V K 1814$, at begrebet i dette værk slet ikke er bundet til det nationale, men derimod til brugen af "folk" i betydningen undersåtter eller - anakronistisk i forhold til Det Gamle Testamente - i betydningen borgere. Her er det afgørende, at begrebet er snævert forbundet med den idealisering af det jødiske folk og det gammeltestamentlige Israels statsdannelse, som 1814-krøniken behandler indgående.

\section{Grundtvigs kendskab til samtidens holdninger til jøder og jødedommen}

For at forstå denne tætte sammenhæng mellem folkelighedsbegrebet og Grundtvigs opfattelse af jødedommen, er det nødvendigt, at man gør sig klart, hvilke billeder af og kilder til jødedommen Grundtvig havde mødt og arbejdet med og kunne gøre brug af under affattelsen af 1814-krøniken.

Begynder man med, hvilke samtidige billeder af jødedommen Grundtvig var påvirket af, bliver det ved læsningen af krøniken klart, at i hvert fald to former for kritik af jødedom og jøder fungerer som implicitte, ikke navngivne diskussionspartnere i værket og altså må have været stærkt fremme i bevidstheden. Det drejer sig dels om teologisk antijudaisme, dvs. en religiøst begrundet afstandtagen fra jødedommen, ${ }^{5}$ dels om det fænomen, den tysk-jødiske politolog Eleonore Sterling (1925-1968) har kaldt for "Frühantisemitismus". Dvs. en mere politisk form for jødehad, som

\footnotetext{
5 Teologisk antijudaisme kan forekomme i kristen teologisk litteratur både med og uden "konkrete Juden" (Grözinger 1999, 65).
} 
eksisterede i det tyske - og danske - kulturområde i de første årtier af det 19. århundrede. ${ }^{6}$

Grundtvig mødte i 1811 en variant af teologisk antijudaisme i første bind af tidsskriftet Theologisk Bibliothek, der i modsætning til tidligere tiders kristne kritik af jødedommen også havde et negativt syn på Det Gamle Testamente. ${ }^{7}$ I tidsskriftet stod artiklen "Om Forskjellen imellem den mosaiske og christelige Religions historiske Dokumentation”, der var forfattet af bladets redaktør, den teologiske professor Jens Møller (17791833). Møllers forsknings- og ansvarsområde var bibelsk eksegese og kirkehistorie, og han kombinerede ganske tidstypisk en historisk-kritisk tilgang til Gammel og Ny Testamente med et supranaturalistisk syn på Jesu guddommelighed og hans underes pålidelighed. Denne anskuelsesform dominerer også artiklen, hvor Møller roser Paulus for at stræbe efter at gøre "Christianismen, den historiske Sammenhæng fraregnet" (Møller $1811,95)$ uafhængig af jødedommen. Endvidere finder Møller inspiration hos den tyske gammeltestamentler Johann David Michaelis (1717-1791) og hos Wilhelm Martin Leberecht De Wette (1780-1849), datidens førende forsker i den gamle pagts bøger. ${ }^{8}$

Med støtte i Michaelis, der sidestiller "Jøder, Deister og Naturalister" (Møller 1811, 89) som kristendommens modstandere, argumenterer Møller for kristendommens overlegenhed i forhold til jødedommen. Hans synspunkt er, at Det Nye Testamentes tekster er langt mere historisk pålidelige end teksterne i Det Gamle Testamente, der hører hjemme i "det mythiske Tusmørke” (Møller 1811, 93). Fra De Wette overtager Møller desuden en skarp kritik af den traditionelle opfattelse af Moses som Pentatheukens forfatter, og det konkluderes, at det ikke længere er holdbart, at betragte moseloven som "en guddommelig Aabenbaring". Ikke desto mindre vil jøderne formodentlig i mange år endnu blive ved med at sam-

\footnotetext{
${ }^{6}$ Tidlig antisemitisme skal med andre ord ikke karakteriseres som kirkelig afstandtagen fra moderreligionen, selv om der går tråde til den teologiske antijudaisme. Fænomenet tager først og fremmest form af advarsler mod jødernes skadelige indvirkning på "den christlichen Staat" (Bergmann 2010, 96), og der argumenteres politisk.

7 Om Grundtvigs kritik af Møllers Theologisk Bibliothek, se Pedersen 2013.

${ }^{8}$ Michaelis vendte sig mod jødernes borgerlige ligeberettigelse, idet han talte om "jüdische "Ausländer" bzw. "Fremdlinge" und deutsche Bürger" (Blum 2009, 554). Til Michaelis" jødefjendtlighed, se videre Löwenbrück 1995, 203 ff.
} 
menblande rabbinske forklaringer med "guddommelige Anordninger" (Møller 1811, 103), mener Møller, og derved gøre sig immune over for historisk kritik.

I de følgende bind af Theologisk Bibliothek fortsætter Møller denne linje ved at bringe en oversættelse af en tekst af De Wette og samtidig drøfte hans tolkning af Pentateuchen som et mytisk epos. Hovedsagen er igen skrifternes manglende historiske pålidelighed. De Wette - og Møller antager bl.a., at den grundlæggelse af "Theokratiet og dets Love" (Møller 1812, 253), som skildres i Mosebøgerne, er en senere lovsamling "der ved en historisk Fiction ere Moses tilskrevne" (Møller 1812, 255).

Lige så formdannede for Grundtvigs synpunkter i 1814 blev beskæftigelsen med Thomas Thaarups oversættelse og udgivelse af Friedrich Buchholz' bog, Moses og Jesus eller om Jødernes og de Christnes intellektuelle og moralske Forhold, fra maj 1813. ${ }^{9}$ Bogen blev startskuddet den litterære jødefejde i sommeren 1813 og rummede klare elementer af tidlig antisemitisme. $^{10}$

I bogen angriber Buchholz både samtidens tyske jødedom og den jødedom, man møder i Det Gamle Testamente. Hovedgrebet er nationaløkonomiske overvejelser over og vurderinger af jødernes tilstedeværelse i Tyskland, der på forunderlig vis trækker tråde tilbage til Israels tidlige

${ }^{9}$ Friedrich Buchholz (på Thaarups titelblad stavet Buchholtz) (1768-1843) levede fra 1800 som fri forfatter i Berlin og kendes i Tyskland som den, der introducerede Auguste Comtes (1798-1857) sociologi og positivisme for et tysk publikum (Kjærgaard 2013, 110 f.). For Schwarz Lausten skal Thaarups motiver til udgivelsen af "dette berygtede skrift fra den tyske litterære jødefejde" søges i, at "man under de elendige økonomiske forhold måtte finde syndebukke, som man kunne vælte al sin frustration og vrede over på” (Schwarz Lausten 2002, 344). Schwarz Lausten vælger her en social og økonomisk forklaring på, at en velrenommeret forfatter som Thaarup - "tidligere medlem af direktionen for Det Kongelige Teater" (Tudvad 2010, 17) - følte trang til at delagtiggøre offentligheden i sin fjendtlige holdning til jøderne. Forklaringen er nærliggende. Thaarup fiskede i hvert fald med sin fordanskning af dette antijødiske skrift fra de tyske debatter 1803-04 i rørt vande, og budskabet vandt genklang, selv om bogen var skrevet med tyske samfundsforhold for øje. Thaarups kommenterede udgivelse af Buchholz er fyldigt behandlet i forskningen (se Davidsen 1880-81; Christensen 1890, 129 ff.; Albertsen 1984 og Lausten 2002, 341 ff.), men ingen har været opmærksomme på forbindelsen mellem teksten og VK 1814.

${ }_{10}$ Bogen optræder som nr. 841 i auktionskataloget over Grundtvigs efterladte bogsamling. 
historie. Buchholzs tolkning af Det Gamle Testamente er en sær blanding af en - i forhold til Møller langt større - tiltro til teksternes historiske pålidelighed og traditionelle udlægninger af jøderne som et amoralsk, grisk og upålideligt handelsfolk - et fænomen som i nyere tysk forskning er blevet kaldt "Wucherstereotyp" (Hortzitz 1999, 20). F.eks. fortolkes historien om Josef som en fortælling om en kanaanæisk familie, der indvandrede og overtog “Ægypternes Bopæle” og drev "Kvægavl, Røverie og Skakkerie i et Land, der fortrinligt var beqvemt til Agerbrug" (Buchholz 1813, 14 f.), og Pentateuchen som beretningen om, hvordan jøderne fra begyndelsen havde en tvivlsom karakter: "Ingen Tid forstode de den Kunst at fremstille den moralske Verdens Phænomener i deres Nødvendighed, men allermindst $\mathrm{i}$ hine Tider, da deres Nationalbøger bleve forfattede" (Buchholz 1813, 17). Ifølge Buchholz brugte Moses religionen til at binde de 12 jødiske "Stammer" (Buchholz 1813, 24) sammen, og han forstås derfor som "Folkeforføreren" (Buchholz 1813, 28), der optrådte som en "Guddommens Repræsentant" (Buchholz 1813, 29). Endvidere udnyttede Moses ifølge Buchholz menneskers frygt for tilværelsens ophav og mening. Netop hermed: "gjorde [han] sin eneste, usynlige Gud, til en National-Gud, (...), der blandt alle Nationer havde udvalgt sig den jødiske til Yndlings-Folk, og som var fast bestemt, med sin ubegrændsede Kraft og Frygtelighed overalt at bane det Vejen" (Buchholz 1813, 35). Imidlertid forstod Moses også, hjulpet på vej af sin svigerfar Jetro (2 Mos 3,1), at "en Lovgivning" var "nødvendig" (Buchholz 1813, 38), og han skabte derigennem "et theokratisk Monarki" (Buchholz 1813, 39) præget af grusomhed og strenghed: "Der var ikke Kirke i Staten, men Stat i Kirken, eller meget mere, der var ingen egentlig Stat at tænke paa, saasom Kirken var Alt" (Buchholz 1813, 41). Til trods for, at bogen prægedes af så markant en religionskritik, at Thaarup i forordet følte sig nødsaget til at lægge et ord ind for "den christelige Lære" (Buchholz 1813, LII), tilslutter denne sig med udgivelsen tydeligvis i mangt og meget den lidet flatterende fortolkning af det gammeltestamentlige Israel: "Egennytte, Grumhed, og Ladhed, er Nationens Særkiende fra dens første Oprindelse” (Buchholz 1813, III). ${ }^{11}$

11 Grundtvig deltog også i den efterfølgende litterære fejde, som det vil fremgå, men nøjedes i 1814 med at forholde sig til Thaarups udgivelse af Buchholz. 
Kilder til Grundtvigs billede af det jødiske folk

Med til tilblivelsen af synet på jødedommen i $V K 1814$ hører naturligvis også Grundtvigs egne studier af GT og læsning af kilder og anden litteratur fra for- og samtiden. Dette kan selvfølgelig ikke efterspores med fuld nøjagtighed. Alligevel synes en række bestemte prætekster og fokusområder at kunne identificeres som bestemmende for hovedgrebet. Bestemmelsen af Grundtvigs tekstlige forlæg kan her i et vist omfang støtte sig til auktionskataloget over Grundtvigs efterladte bogsamling.

En afgørende forudsætning er i første omgang Grundtvigs Bibellæsning, som naturligvis strækker sig tilbage til barndommen, men som efter 1810 var præget af en række særlige tolkningsmønstre af bestemte tekstsammenhænge. Især $V K 1812$ vidner om en klar inspiration fra det deuteronomistiske historiesyn i Det Gamle Testamente. Historiens lange forløb ses her som, "hvorledes det går folket, når det svigter Jahve og vender sig til andre guder" (Otzen 1977, 26). En anden markant tendens i årene 1811-14 finder man i udlægningen af 1 Mos 49,10 og 5 Mos 29,21-27 som spådomme om Israels sørgelige skæbne efter nationens oprør mod romerne år 70 e. Kr. Det er dog først i affattelsen af $V K 1814$, som det senere vil fremgå, at man finder de markante nedslag af den deuteronomistiske skepsis over for kongemagten, som hører med til Grundtvigs politiske anskuelser og brug af folkelighedsbegrebet i dette værk.

Væsentligst blandt de nytestamentlige påvirkninger af Grundtvigs holdning til jøderne i 1811-13 er utvivlsomt Paulus' brev til Romerne. Det eskatologiske håb for Israel, som Paulus giver udtryk for, knytter Grundtvig sammen med en række gammeltestamentlige skriftsteder (f.eks. 5 Mos, 30,1-5 og Es 2,2-3), som han udlægger som profetier om det jødiske folks tilbagevenden til Palæstina. Med denne tolkning af Israels genoprettelse, gør Grundtvig brug af det, den tyske jødiske historiker Hans-Joachim Schoeps (1909-1980) har kaldt for den "biblisch-chiliastische Typus" (Schoeps 1965, 7 f.) af, hvad han betegner som filosemitisme. Det vil sige en kærlighed til og et forsvar for det jødiske folk, som er knyttet sammen med eskatologiske overvejelser over begivenheder i forbindelse med Jesu synlige komme ved tidernes ende. Som det vil fremgå, forekommer filosemitismen i Grundtvigs forfatterskab allerede i 1811, men tydeligst fra 1813 og kommer også til orde i $V K 1814$ i bevidst opposition til samtidens teologiske antijudaisme og tidlige antisemitisme. 
Grundtvig er i 1811-14 og i særdeleshed i 1814-krøniken endvidere tydeligt påvirket af læsningen af Luthers Genesiskommentar i Walchs tyske oversættelse. ${ }^{12}$ Først og fremmest er det Luthers billede af menneskets liv eller samfundet i paradiset, der overtages. Tydeligt er det, at Grundtvig har forstået, at Luther i forbindelse med beskrivelsen heraf anvender sin lære om de to regimenter, "das geistliche" og "das weltliche Regiment" (Andersen 2010, 20; 22). De to regimenter udgøres af henholdsvis evangeliet og den lov, der som tugt skal være rådende i verdslige sager. Det verdslige regimente har for Luther rod i "dem Amt der Eltern" (Andersen 2010, 28), og derfor fører han i Genesiskommentaren "das Hausregiment" (Luther 1535-45/1880, 127; 300) tilbage til menneskets "ersten Eltern" (Luther 1535-45/1880, 221) og taler om Adams og Evas forhold som en "Einsetzung von des Haus- und Ehestandes" (Luther 1535-45/1880, 160). Endvidere fremhæver kommentaren med et synspunkt, Grundtvig ligeledes skulle tilslutte sig, at man i det jordiske liv med børn i hjemmet møder "ein dunkles Bild und Ueberbliebsel der seligen Beiwohnung im Paradiese" (Luther 1535-45/1880, 162). Samlivet mellem forældre og børn afspejler paradislivet, hvor man ikke kendte til "Polizei", fordi "das Weltliche Regiment und Ordnung” (Luther 1535-45/1880, 127) ikke var nødvendigt. Alligevel er forældremyndigheden basis for det verdslige regimente.

Lige så væsentlig for etableringen af folkelighedsforståelsen i $V K 1814$ er samtidens og det forudgående århundredes diskussion af den lutherskortodokse tradition for at legitimere den enevældige kongemagt med gammeltestamentlige motiver og Luthers toregimentelære. Det afgørende er, at toregimentelæren under enevælde og ortodoksi i mangt og meget var blevet udbygget med gammeltestamentligt materiale, men på en sådan måde, at de deuteronomistiske teksters reserverede holdning til kongemagten udelukkedes. I dansk sammenhæng kan henvises til "Enevældens store Teoretiker i Danmark, Professor Hans Wandal (1624-75)” og til den danske kongelov fra 1665, der fastslår, at "Kongen er Guds Stedfortræder paa Jorden" (Kornerup 1959, 358). De teokratiske argumenter for kongemagten blev herved tydelige. Ved siden af denne teologiske legitimering af enevælden møder man i en dansk sammenhæng også spor af samtidens kontraktteorier. I den danske kongelov af 1665 begrundes enevælden

12 Walchs værkudgave, hvor alle Luthertekster foreligger på tysk, optræder som nr. 735-6 i auktionskataloget over Grundtvigs efterladte bogsamling. 
med, at "Rigens Raad og samptlige Stænder, Adel og Uadel, Geistlig og Verdslig" frivilligt har bevæget sig til "(...) deris forrige Kaar og Wallrettighed at affstaa og begiffve" og gøre den tidligere håndfæstning "død" og "magtesløs" og gennem denne "uforanderlig[e] GrundvoldsLow" gøre Danmark til et "EenevoldsArffveKongedømme"."13 Kongeloven understreger samtidig, at undersåtternes frigørelse af kongen skal opfattes som en kærlighedsgerning. Kongeloven gav altså ikke nogen indskrænkning af magten, men lod det kontraktteoretiske element komme til udtryk i en frigørelse af kongemagten, der nu blev enevældig. ${ }^{14}$ Det vil nedenfor blive klart, at Grundtvig ud fra sin læsning af Det Gamle Testamente i 1814-krøniken nok accepterer dette - af ham benævnte - patriarkalske kongedømme for en periode af det danske folks historie, men at han først og fremmest med oldtidens Israel som model forestillede sig, at det måtte ske en udvikling i retning af et mere opinionsstyret kongemagt.

Grundtvig har også kendt til Holbergs bog, Jødernes Historie, fra 1742, uden at det synes at have fået mærkbar betydning i 1814-værket, men nok $\mathrm{i}$ årene forud. ${ }^{15}$ I Holbergs værk finder man blandt meget andet en lettere teologisk antijudaistisk tendens med rødder i vesterlandsk teologi helt tilbage til Augustin (354-430), der i en ofte citeret prædiken gør rede for, at når jøderne er "losgerissen (...) von ihrer Heimat und über die ganze Welt zerstreut", er det "zum Zwecke der Zeugenschaft". Jødernes fortsatte eksistens efter år 70 er for Augustin villet af Gud. Deres kanon vidner om, at de gammeltestamentlige tekster, der profeterer om Kristi komme, ikke er "gefälscht" (Blumenkranz 1946, 176f). Tanken om jøderne som bærere af vidnesbyrd om kristendommens sandhed overtog Grundtvig fra Holberg, men uden de negative konnotationer, den havde hos ham.

I VK 1814 sporer man derimod tydeligt inspirationen fra kulturfilosoffen J.G. Herder (1744-1803), især fra to værker, Vom Geist der Ebräischen Poesie 1782 og Briefe, das Studium der Theologie betreffend 1785.16 Værkerne indeholdt en for sin tid ganske enestående interesse for og positiv holdning til Det Gamle Testamente, men lægger samtidig ganske

${ }^{13}$ http://danmarkshistorien.dk/leksikon-og-kilder/kongeloven (Set 1. nov. 2014)

${ }^{14}$ Jf. Danmarkshistorien.dk

15 Bogen optræder som nr. 1814-15 i auktionskataloget over Grundtvigs efterladte bogsamling.

${ }^{16}$ Herders Sämmtliche Werke 1805-10 optræder som nr. 3882-93 i auktionskataloget over Grundtvigs efterladte bogsamling. 
tidstypisk afstand til den senere jødedom. ${ }^{17}$ I det førstnævnte værk peger Herder på, at det jødiske folks historie i modsætning til andre folkeslags er sammenhængende og uden brud, og at det jødiske folks eksistens ind $\mathrm{i}$ det 18. århundrede - i en genklang af Augustin - vidner om Det Gamle Testamentes historiske pålidelighed. Herder slår fast, at "nur Frechheit oder Verzweiflung" kan benægte, at "Israel sei oder je gewesen" (Herder 1785/1994, 252). Den vigtigste inspirationskilde til Grundtvigs fortolkning af det jødiske folk i $V K 1814$ er imidlertid Herders redegørelse for, hvordan Det Gamle Testamente udgør et poetisk mesterværk fra oldtiden, og hvorledes selve det hebraiske sprog ifølge sit væsen er poetisk. I Vom Geist der Ebräischen Poesie modstiller Herder det oprindelige hebraiske "Dichtersprache" med det, der er "Schulmässig und Rabbinisch" (Herder, 1782/1993, 690), og skelner mellem de gammeltestamentlige jøders urgamle dannelses "Genius" og "Das arme Volk", der siden hen er "zerstreut” (Herder, 1782/1993, 678) i verden. Der er i Det Gamle Testamente tale om "eine Poesie der Kindheit unsres Geschlechts", som i positiv forstand er præget af "die simpelsten Vorstellungsarten" (Herder, 1782/1993, 690). Et andet væsentligt motiv er de teologiske breves redegørelse for, at det jødiske folk "war und ist das ausgezeichneste Volk der Erde" (Herder 1785/1994, 252f.), altså et udvalgt folk. Hos Herder kan man dog konstatere en vis selvmodsigelse, når han på den ene side peger på Israels digteriske gaver, men samtidig understreger, at udvælgelsen ikke skyldes Israels naturlige kvaliteter. Israel er jo, som det eksempelvis fremgår af 5 Mos 9,4-6, et "widerspenstiges, hartes (...) Volk". Guds kærlighed og ledelse er således ikke begrundet i folkets karakter, men er "eine freie Wahl des Vaters" (Herder, 1785/1994, 254).

Herderpåvirkningen knyttes i 1814-krøniken, som det vil fremgå, sammen med indoptagelsen af begrebet "Normalvolk", som Grundtvig havde mødt hos filosoffen J.G. Fichte (1762-1814). I Die Grundzüge des Gegenwärtigen Zeitalters (1806) arbejder Fichte med en idealkonstruktion, en "Annahme eines ursprünglichen Normalvolkes, das durch sein blosses Daseyn, ohne alle Wissenschaft oder Kunst, sich im Zustande der vollkommenen Vernunftkultur befunden habe" (Fichte 1806/1845/1846,

17 Herders ubehag ved jødernes tilstedeværelse i Europa kommer til udtryk efter 1801 i hans tidsskrift Adrastea. Vedr. Herders forhold til jødedommen se eksempelvis Weissberg 1994, 193 ff.; Menze 1994, 213 ff.; Menges 1996, 459 ff.; Menze 1996, 471 ff.; 
133). ${ }^{18}$ I Reden an die Deutsche Nation (1808) gør Fichte rede for "die Grundzüge der Deutschen als eines Urvolkes” (Fichte 1808/1845/1846, 359), et folk, der har bevaret sin etnicitet og sit sprog rent. Forestillingen om urfolket har den tyske jødiske filosof Micha Brumlik (1947-) karakteriseret som en overførsel af den jødiske udvælgelsestanke på det tyske folk (Brumlik 2000, 114).

\section{Udviklingen af Grundtvigs billede af det jødiske folk}

Før 1810 er Grundtvigs holdning til jødedom og jøder i et vist omfang præget af afstandtagen. I afhandlingen Om Religion og Liturgie fra 1807 betegner Grundtvig "de gamle Religioner" som "Poesie" (US I, 143) og gør rede for, at "baade Grækers og Jøders og Skandinavers Historie taber sig i en gylden Alder, da Guderne vandrede paa Jorden, da det Himmelske og Jordiske faldt sammen i en Idee" (US I, 142). Den gyldne alder er skildret mytisk i Første Mosebogs "Uskyldighedstilstand", og Grundtvig udlægger såvel skabelsen i Guds billede som syndefaldsberetningen allegorisk som billeder på filosofiske begreber. Grundtvig viderefører denne udlægning gennem en sammenligning af jødisk og nordisk gudelære, hvor han klart fortrækker den nordiske. Det jødiske folk er, trods en god begyndelse, faldet i den snare kun at beskæftige sig med det timelige liv. Israels selvforståelse som et udvalgt folk endeliggør dets religion, der træder "i Nationalismens Tjeneste", og i forbindelse med den romerske besættelse styrkes tendensen, idet den jødiske tro nu indeslutter sig "i Tilværelsen" (US I, 144). Den nordiske mytologi har i 1807 i kraft af sin betoning af det evige højere status end de jødiske tekster, der er præget af Israels selvforståelse som Guds ejendomsfolk. Dette er dog ikke det eneste synspunkt, som fremsættes i disse år. I Grundtvigs undervisningsmanuskript til det Schousboeske Institut fra årene op imod 1810 møder man en begejstring for Grækenland - ikke Israel eller Norden - som "den menneskelige Aands Højde” (Michelsen 1956, 46).

18 Bogen optræder som nr. 4080 i auktionskataloget over Grundtvigs efterladte bogsamling. 
Billedet ændrer markant karakter efter 1810. I to debatindlæg i Nyeste Skilderie af Kjøbenhavn ${ }^{19}$ fra henholdsvis 1811 og 1812 om den gamle pagts bøgers teologiske betydning appellerer Grundtvig til at styrke det hebræiske Sprog ved Det teologiske Fakultet, hvor det misrøgtes. ${ }^{20}$ Samtidig med dette forsvar for studier af Det Gamle Testamente polemiserer han dog mod samtidens jødedom. Den "udvortes Lovmæssighed", som oplysningsteologerne hylder, er en videreførelse af den jødiske gerningsretfærdighed. Som fremstillet i 2 Kor 3,12-18 hviler der "et Skjul" over jøderne, når de læser Det Gamle Testamente, idet de ikke fortolker teksterne som Kristusprofetier. Dette skjul vil imidlertid blive taget bort, når jøderne "omvende sig til Herren" (Grundtvig 1812, 626), siger Grundtvig. I landemodetalen "Et Par Ord om Geistlighedens Videnskabelighed eller om kristelig og præstelig Lærdom” fra 1811 (trykt 1813) gentager Grundtvig sin appel til fremme af kundskaber i det hebraiske sprog (Grundtvig 1811/1813, 56). Samtidig går han nøjere ind på Israels skæbne og betydning:

Jeg vil kun nævne det jødiske Folk, hvos uomtvistelige Historie som et Heelt, er et langt større Underværk end Gangen gennem det røde Hav eller nogen anden enkelt Hændelse, der synes utrolig; ja hvis attenhundredaarige Vantro taler nok saa høit som Folkenes Tro om Kristi Guddom (Grundtvig 1811/1813, 54f.).

Denne fremstilling af et kontinuerligt forløb vidner om påvirkning fra Herders breve om det teologiske studium og bliver, som det vil fremgå, helt centralt i $V K 1814$ som et hovedargument for jødernes betydning.

19 "Et Par Ord i Anledning af den gamle Præsts Skrivelse til Fyens og Ribes kaarede Bispe" (1811) og "Foreløbigt Svar til Hr. Doctor Larsen i Anledning af hans Par Ord i Skilderiet” (1812).

${ }^{20}$ Grundtvig taler ud af personlige erfaringer. I dagbogen fra 1804 skriver han, at han "stedse" (...) har (...) været en Stymper i det ebraiske Sprog, og (...) haver aldrig anvendt nogen Fliid derpaa” (Grundtvig 1804/1979, 36), hvad også hans beretning om sin teologiske embedseksamen vidner om. Til Grundtvigs hebraiskkundskaber, se Toldberg 1946, 45. K.E. Bugge gør rede for, at Grundtvig “i september 1803 særdeles flittigt besøgte" (Bugge 1965, 58) gammeltestamenteprofessoren Hornemanns forelæsninger, til trods for at han dårligt mestrede hebraisk. Grundtvig fortæller selv i en skriftlig beretning om sin embedseksamen om sin “Tyndhed i det palæstinensiske Tungemaal” (Grundtvig 1804/1979, 40). 
I Optrin af Nordens Kampeliv fra 1811 indgår ligeledes en række overvejelser over Israels historie efter år 70 i en samtale mellem de to nordboer Torkild og Sigurd. Bag Grundtvigs tekst aner man Holbergs jødiske historie og hans tale om spådommenes fuldbyrdelse og om jødernes adspredelse. Det jødiske folks fortsatte eksistens som et folk, der i overensstemmelse med de gammeltestamentlige profetier skulle "adsplittes" blandt folkeslagene, "men overalt sig selv dog ligne", er et "Vidnesbyrd" (PS I, 349f.), der $-i$ en videreførelse af den augustinske tradition for at betone jødernes rolle efter år 70 som vidner - kalder mennesker som Sigurd til troen. Samtidig forkynder jødernes landflygtighed og undertrykkelse dom over dem, hvor "Forhærdelse" (Rom 11,25) har indfundet sig, dvs. der, hvor man afviser Kristus. Scenen afsluttes med en angivelse af det paulinske håb for jøderne, men samtidig med klare hentydninger til Romerbrevets forventning om, at kun en begrænset gruppe af jøderne omvender sig.

I $V K 1812$ skildres i forlængelse af Herder "Israeliternes eller Jødernes Historie, som, en uafbrudt Kæde fra de ældste Tider af, der ved Guds forsyn er opbevaret i deres "hellige Bøger" (US II, 210). Som det vil blive klart nedenfor, er Grundtvig sandsynligvis her under indflydelse af Herders billede af det jødiske folk som et digterfolk.

Det paulinske håb for jøderne fra Optrin af Nordens Kampeliv danner også baggrund for Grundtvigs indlæg i den litterære jødefejde i Til Fadrenelandet om dets Tarv og Fare fra sommeren 1813. ${ }^{21}$ Indlægget bærer præg af en typisk dobbelthed i synet på jøderne, som Grundtvig også siden hen kunne forfægte. For det første formulerer han i skriftet nogle af samtidens fordomme, de forestillinger om ågerjøden, der indgår i den førnævnte "Wucherstereotyp". Han gør således rede for, at en "Kræmmeraand" har "besat" det "ulykkelige" jødiske "Folk" (US II, 725) og i tilknytning til Thaarups karakteristik af jøderne som en "Stat i Staten" (Buchholz 1813, XVI) konstaterer han, at selv de bedste jøder har svært ved at opfatte sig "som Lemmer paa et Statslegeme, de hverken ved Herkomst, Tro eller Sprog synes knyttede til” (US II, 725). For det andet er

21 Grundtvigs indlæg er senest behandlet af Martin Schwarz Lausten i monografier og i artikelform (Lausten 2002, 2013). Schwarz Lausten leverer en grundig gengivelse og analyse af de dele af Grundtvigs tekst, der omhandler hans samtids jødedom. For Schwarz Lausten samler Grundtvigs tanker sig “om tre temaer, som dog flettes ind i hinanden uden skarpe adskillelser: jøders karakteregenskaber, jødefejden og forholdet mellem kristne og jøder" (Lausten 2002, 372). 
bogen overordnet domineret af et forsvar for jøderne. Grundtvig imødegår "den ligesaa ukiærlige som bagvendte Tale, Man længe om dette Folk har ført i Husene og nu fører paa Prent” (US II, 725) om jøderne. I forlængelse heraf gør han rede for, at de gammeltestamentlige skrifter "ogsaa ere de Christne en Helligdom" (US II, 726), at der hos jøderne er "mindre Ugudelighed" og mere "Følelse af Samvittighed" og "udvortes Tugt" (US II, 722) end hos mange kristne, og at jøderne ifølge profeten Jeremias (Jer 29,7) er forpligtede til at udvise moralsk adfærd mod de mennesker, de bor iblandt. Med støtte i Rom 9-11, Salme 44 og Es 2 udformer Grundtvig ydermere håbet om jødernes tilbagevenden til Israel og om det hebraiske sprogs genoplivelse. I "de sidste Dage, naar Herren har renset sit Folk, og skinnet i Israels Hjerte" skal det jødiske folk med 2. Kor 3,18; 4,6 "oplyses til at erkjende Guddomsklarheden i Jesu Christi Guds Billedes Aasyn” (US II, 728). Igen ses her Grundtvigs bibelsk-eskatologiske filosemitisme, dvs. hans endetidsforventninger om jødernes omvendelse, som også er af betydning i $V K 1814$.

Et sidste vigtigt skridt på vejen frem mod krøniken i 1814 udgør En liden Bibelkrønike for Børn og Menigmand fra foråret 1814, hvori Grundtvig udfolder den afstamningslære, der siden hen præger forfatterskabet. Grundtvig nævner kort, at "Menneskene" efter syndefaldet og Babelstårnet "adspredtes paa Jordens Kreds", at semitterne bosatte sig i Asien, Chams efterkommere i Afrika og Jafetiderne i Europa, og at "vi", dvs. danskerne, "ere (...) dem" (Grundtvig 1814a, 8). ${ }^{22}$

\section{4-krøniken}

VK 1814 udsendtes kun godt og vel en månedstid efter En liden Bibelkrønike for Børn og Menigmand (Johansen I 91; 95) og kun omkring halvandet år efter 1812-krøniken. Værket skulle ifølge titlen udgøre første bind

\footnotetext{
22 Toldberg har i Grundtvigs Symbolverden $304 \mathrm{f}$. peget på den franske reformerte teolog Samuel Bocharts (1599-1667) brug af Josephus Ben-Gorion i Geographia Sacra seu Phaleg et Canaan (1646) som kilde til Grundtvigs identifikation af "Dodanim" og danskerne i Europa, Frankrig og Napoleon fra 1815. Bestemmelsen af danskerne og europæerne i al almindelighed som efterkommere af Jafet forekommer imidlertid, som det bliver klart, i Grundtvigs afstamningslære allerede i 1814 . Se yderligere Albeck 1955, $122 \mathrm{ff}$.
} 
af en stort anlagt verdenshistorie, et projekt, der medførte udsættelsen af andre planlagte tiltag. ${ }^{23} V K 1814$ havde til hensigt at være en forbedring i forhold til det "Stymperværk af en Verdens Krønike", som i 1812 blev skrevet i "en bogfattig Præstegaard" (VK 1814, X), men formålet var uændret i forhold til det tidligere værk. Som i 1812 skulle verdenskrøniken dertil være "christelig" (VI), for "Bibelens Lys" kan alene opklare "det Mørke, der hviler over de gamle Hedninges Levnet" (IV). "Bibelen” er "den eneste duelige Ledetraad" i forbindelse med kortlægningen af "Menneskeslægtens ældste Historie” (XI).

Grundtvig relancerer og rehabiliterer derved bevidst ældre, bibelsk funderet historieskrivning og stiller den op som sandt alternativ til samtidens videnskabelige undersøgelser af fortiden. Først og fremmest beviser Bibelen selv sin sandhed, da dens profetier er blevet opfyldte op gennem historien og virkeliggøres med en sådan styrke i samtiden, at de ikke kan benægtes. Grundtvig knytter i den forbindelse til ved sin kirkehistoriske fortolkning af Johannes Åbenbaring i manuskriptet Lidet om Jesu Kristi Aabenbaring ved Apostelen Johannes fra $1810 .{ }^{24}$ Det står således tydeligt:

at den Time er kommet, da Historien skal begynde at aflægge sit store Vidnesbyrd om Christo, og at det hører til Guds Husholdning kan vi godt forstaae, ja see det klarlig af Skriften, thi hvortil vare alle Spaadomme, dersom Man ei skulde agte paa deres Opfyldelse, hvortil var Johannes Aabenbaring, hvor Christi Menigheds Hændelser indtil Dagenes Ende forkyndes, dersom Man ei, ved at beskue Historien i Herrens Lys, skulde berede den store Time, da det skal sees aabenbarlig, at den Gud, Som styrer Jorderige, lod sin Tjener see de uvordne Ting, den Time, da Bibelen ved sine Spaadomme saaledes kundgiør sin guddommelige Oprindelse, at kun Djævletrods kan nægte den (VIIf.).

${ }^{23}$ VK 1814 er således ét af flere værker, Grundtvig intenderer at skrive. Den lille bibelkrønike bliver virkelighed, verdenskrøniken gøres ikke færdig og en "længere Tale om Fædrenelandet", som også annonceres i den lille bibelkrønike som en "Bog om Guds Førelser med vore Forfædre" (1814A, XV), planlægger Grundtvig at gemme "til en egen Bog" ( $V K$ 1814, XI).

${ }_{24}$ Til de forskellige typer af fortolkninger af Johannes Åbenbaring, se Mosbech 1934. 
Den uudtalte forudsætning for Grundtvigs tiltro til, at historien nu vidner om kristendommens sandhed, er her, at hver af de syv menigheder i Johannes Åbenbarings sendebreve med menighedsenglen som leder repræsenterer en kirkeafdeling i kristenhedens historie. Den sjette menighed, Filadelphiamenigheden, er samtidens nordiske eller danske menighed, og denne menighed er altså i overensstemmelse med Johs Åb 3,8 stillet foran historiens åbne dør og er i stand til at tolke og forstå historien. ${ }^{25}$

\section{4-krønikens billede af det jødiske folk}

1814-krønikens overordnede billede af optimisme på vegne af det unge 19. århundrede står imidlertid side om side med billedet af tiden som præget af vantro og frafald fra kristendommen. Med tanke på Jens Møller gør Grundtvig rede for, at han lever i:

en Tid, da selv boglærde Mænd med christen Troe agtede det for lovligt og gavnligt, at adskille hvad Gud har sammenføiet, det Gamle og Ny Testamente, ja da selv en Theologisk Professor, som indrømmer Jesu Sandhed og himmelske Natur :) tør tale om Mythologie i Moses Skrifter", idet han paastaar, Pentatheukens Efterretninger ere ei mere tilforladelige end de Romerske Præstekrøniker (XVIII f.). ${ }^{26}$

Grundtvig har, som det fremgik af ovenstående omtale af $\mathrm{Om}$ Religion og Liturgie, selv tidligere, efter at han i årene op imod 1810 havde "annammet Tro paa Christus", ment, "man kunde forstaa Moses første Kapitler allegorisk" (XXIXf.). Nu argumenterer han for skabelsesberetningens

${ }^{25}$ Lidet om Jesu Kristi Aabenbaring ved Apostelen Johannes er for størstedelens vedkommende transskriberet og publiceret i Grundtvig-Studier 1956, 64 ff. af William Michelsen. Slutningen blev offentliggjort af Steen Johansen i GrundtvigStudier 1959, $99 \mathrm{ff}$.

${ }^{26}$ Jens Møller spiller i det hele taget en ikke ubetydelig rolle som Grundtvigs modstander i fortalen til $V K$ 1814. Grundtvig omtaler Møllers anonyme anmeldelse af VK 1812 i "Litteraturtidenden", hvor Møllers "smaa Drillerier" er blevet suppleret med en ros til "Doctor Badens grove Skiældsord i Athenes Gadedør, Ord, som dog visselig ingen skikkelig Mand, hvor uenig han var med mig, skulde tilegne sig" (X). Hertil kommer Grundtvigs imødegåelse af Møllers kritik af titlen "Krønike" (XXXVI ff.). 
bogstavelige sandhed. Urhistorien er et led i jødernes historie, derfor er den for Grundtvig pålidelig historieskrivning, og denne sammenhængende, jødiske historie opklarer og belyser på afgørende vis verdenshistorien. Under tydelig påvirkning fra Herders breve om det teologiske studium og i tilknytning til sin karakteristik af den jødiske historie som "et Heelt" i Et Par Ord om Geistlighedens Videnskabelighed kan Grundtvig på den baggrund slå fast, at det er:

vitterligt, at mellem alle de Folkefærd i Verden, vi kiende noget til, ere Jøderne de eneste, som have en fuldstændig Historie, og allerede dette burde jo øiensynlig giøre Jødernes Historie til den vigtigste, ja sikkerlig vilde den og af Alle ansees derfor, dersom den ei bød Menneskene tro, hvad Mange ei vil tro, kun dette, kun dens ubrødelige Sammenhæng med Christendommen skiller den i uchristelige tider ved en Hæder, den i sig selv har den retmæssigste Fordring paa, ei alene ved sin Fuldstændighed, men ogsaa ved den liflige Enfoldighed, hvormed den er beskrevet, ved det Folks Vigtighed, hvis Levnet den afbilder (XX). ${ }^{27}$

Grundtvigs tiltro til Det Gamle Testamentes gavn og troværdighed fornægter sig ikke i den forbindelse. "Jøderne have en Krønike og det heel omstændelig om Folkets Hændelser lige fra Moses Dage igiennem mange Aarhundreder" (181), og denne krønike er pålidelig. Gud, der er god, har "tilladt" den jødiske indflydelse gennem Gammel Testamente i "henved to Aartusinder". Derfor kan påvirkningen fra jøderne heller ikke, som Buchholz mener, have været skadelig, men må have været god, hvilket yderligere fremgår af, at "Jødernes Indflydelse" er "bevirket ei ved, men imod verdslig Magt ved en underlig usynlig Kraft". Formodentlig med en reference til Thaarups afstandtagen fra Buchholz' religionskritik, betoner Grundtvig, at "De færreste vover (...) at kalde kristendommens Indflydelse skadelig" (XXI). Netop "Jødernes Historie" er den bedste kilde til kundskab om menneskehedens ældste tider, og Grundtvigs ønske om at rehabilitere Det Gamle Testamente som grundlag for en troværdig hi-

27 Omtalen af den jødiske histories "liflige Enfoldighed" klinger af Herders ovennævnte omtale af den hebræiske poesis storladne simpelhed i Vom Geist der Ebräischen Poesie. 
storieskrivning er forbundet med en bestræbelse på at vise, at Israel er verdenshistoriens betydeligste nation.

I VK 1814 sigter Grundtvig således ikke blot mod at genoprette tilliden til Det Gamle Testamente, men også mod at tegne et andet billede af det jødiske folk end det, han har mødt i samtiden. I kontrast til Goethetidens idealisering af det antikke Grækenland fremhæver Grundtvig nu i forhold til det tidligere omtalte undervisningsmanuskript jødisk poesi, historieskrivning og filosofi over for de tilsvarende græske. Eksempelvis finder man i den gammeltestamentlige litteratur "flere sunde Leveregler og dybe Blik i Menneskets (...) Vilkaar og Bestemmelse" end hos "alle Grækenlands Philosopher" (XXIII) tilsammen.

Det jødiske folk er "det vigtigste og mærkeligste", dvs. det mest bemærkelsesværdige, "Folk i Verden" og har gennem kristendommens historie "havt en Indflydelse saa udbredt og langvarig" (XX) som ingen anden nation. Indflydelsen står imidlertid i kontrast til den holdning, jøderne møder og har mødt op gennem tiden. Formodentlig bl.a. med tanke på den litterære jødefejde omtaler Grundtvig derfor jøderne som "det foragtede og bespottede Folk" (XIX) og gør rede for, at "Verdens Skikkelse" er forvandlet "ved nogle faa Bøger og Mænd, som udginge fra et dunkelt Folk i dets haanlige Alderdoms Dage” (497). Grundtvig tænker her på kristendommen og Det Nye Testamente, der fremkom, da det jødiske folk var blevet gammelt og så at sige havde opfyldt sin historiske bestemmelse. Jøderne var endvidere, som Grundtvig også havde sagt i Optrin af Nordens Kampeliv, blevet "adspredt over al Jordens Kreds" og har "vanket ustadigt omkring over i [sic] 1700 Aar", de er "Udlændinge" der, hvor de bor, og er der "til Spot og Forhaanelse" (180).

Grundtvig viderefører i krøniken på en ny måde den blanding af teologisk antjudaistisk kritik og anerkendelse af jødernes religiøsitet, som kendes fra den førnævnte skrivelse til Dr. Larsen fra 1812 og Til Fadrenelandet om dets Tarv og Fare. Med skriftstedet "de skal tro paa dig evindelig" (2 Mos 19,9) slår han fast, at jøderne fortsat "læse udi Mose Bog og agte det for hint værste Rygte, at de skulde være vegne" derfra, til trods for at den "Lov", som blev givet ved Moses, "blev hadet og glemt" (180) blandt dem. $\mathrm{Og}$ - med baggrund i 1814-krønikens nedenfor analyserede karakteristik af det jødiske folk som et digterfolk - møder man Grundtvigs paulinsk prægede eskatologiske forventninger om Israels kommende accept af Jesus af Nazareth som Messias. Grundtvigs forventninger om jødernes om- 
vendelse $\mathrm{i}$ endetiden korresponderer med hans overbevisning om at leve i den tid, hvor historien, dens forløb og mål bliver åbenbar for alle, fordi tidernes ende er nær. Man kan med profeten Joel kap. 3 "vente store Syn i Israel, saasandt" jøderne "kun omvende sig af Hjertet til Jehovah", som det er "forkyndt i Lovens Bog" (292), dvs. i den førnævnte forudsigelse i 5 Mos 30.

Som i Til Fedrenelandet om dets Tarv og Fare ses her i $V K 1814$ ved siden af den dominerende filosemitisme igen en række eksempler på, hvordan Grundtvig benytter den såkaldte "Wucherstereotyp". Men i krøniken drejer det sig om en kritik af de andre semitiske folk. Grundtvig betragter som i den lille Bibelkrønike fra samme periode Noahs tre sønner, Sem, Kam og Jafet, som menneskehedens stamfædre og knytter tre sprogfamilier til hver: "Sem er de Aandeliges, Japhet de Hjerteliges og Cham de Legemliges Fader" (55). ${ }^{28}$ Derfor er "Indbildningskraften (...) mest levende hos Sems Afkom” (VK 1814, 63), og hans børns ætlinge udgør "de mest poetiske Folkefærd" (167). De "Semitiske Folk" er "af Beskaffenhed” ikke "historiske" (379), men poetiske, og Sem er "Stamfader til alle dem der have brugt et Tungemaal, Ebræernes Ligt" (58). Hans efterkommere er:

Aandens Børn, der i deres bedste Slægter og i Slægternes favreste Dage kaarede Hyrdelivet, og i deres værste vandrede bag de belæssede Kameler giennem Ørken, eller strakde sig i Mag paa de bløde Hynder, og stirrede paa Guldet og Sølvet som før paa Solen og Maanen og Himmelens Stjerner (500f.).

Dobbeltheden fornægter sig ikke. Det er også baggrunden for, at semitterne præges af to tendenser eller rettere to erhverv, der begge forudsætter nomadelivet. "Indbildningskraftens Førstefødte (...) maatte (...) elske Mag og sagte Vandring og uindskrænket Frihed” (500), en livsform, der er knyttet til såvel fædrift som handel. Pointen er, at det åndelige semitiske tungemål egentlig er forbundet med, at semitternes blik er rettet opad mod det himmelske, men at blikket i visse grene af slægten i stedet vendes nedad mod jordens æxlle metaller, der erstatter de strålende himmellege-

${ }^{28}$ Grundtvig udlægger under inddragelse af den hebraiske rod (Patzach) bl.a. "Japhets eller Japets Navn" som dét at "udbrede og oplade sit Hjerte" (53) og angiver dermed, at jafetiderne er præget af følelsen. 
mer. Herved opstod handlen som den traditionelle jødiske næringsvej i de europæiske lande for jøderne efter år 70 .

Men udgangspunktet var altså et andet. Af de fire grundtyper, som menneskets arbejde med at skaffe sig føden falder i, "Fædrift, Agerdyrkning, Jagt og Fiskeri” (68), blev Abrahams ætlinge og dermed "Israels Børn" nemlig oprindeligt ikke handelsmænd, men "Hyrder". Hyrdeerhvervet er så at sige den ideelle livsform for det menneske, "som helst sysler i Aanden med det Usynlige” (68f.). Grundtvig arbejder allerede her i VK 1814 med tanken om gudsbilledets bevarelse efter syndefaldet. Hos ethvert menneske er der "en Levning af den medskabte Herlighed (...) naar Hjertet bevæges, opvarmes og opløftes ved det Yndige og Store” (38). I den refererede sammenhæng oversætter Grundtvig æstetikkens grundbegreber "das Schöne” og "das Erhabene” til dansk og føjer æstetik og gudserkendelse sammen i billedet af hyrdelivet. ${ }^{29} \mathrm{I}$ "alt hvad der omringer ham", altså i naturen, ser Hyrden "Spor af det Usynlige" (68). Hyrdens "ustadige Liv" er snævert forbundet med, at han stoler på Gud og ikke, som den fastboende, på sit gods og guld. Hyrderne har "fælleds Græsgange" (69), hvorimod den fastboende afsondrer sin rigdom fra andre. Hyrdelivet kommer da det paradisiske idealliv nærmest.

Det "Kiøbmandsskab", som siden hen er blevet det bærende erhverv for jøderne, blev først nødvendigt efter syndefaldet, "hvor de adskilte Lande ei frembringe Alt hvad der høre til deres Indbyggeres Nødtørst". Derfor blev handel uundgåelig, men handelen har også skabt "venligt Samkvem mellem Folkene", "Virksomhed" og "Udbredelse af nyttig Kundskab" (528). Alligevel tegner der sig et negativt billede af handelen blandt de med jøderne beslægtede semitiske folkeslag. Udtrykket "Kræmmeraand", som Grundtvig benyttede i Til Fadrenelandet om dets Tarv og Fare om jøderne, anvendes i $V K 1814$ dels i karakteristikken af fønikerne, som

${ }^{29}$ Begrebsparret er almindeligt i samtidens tyske æstetiske litteratur. F.eks. kan der henvises til Herder, der i sin karakteristik af den gammeltestamentlige digtning i Vom Geist der Ebräischen Poesie taler om det "Erhabene" i forbindelse med himlens uendelighed og umålelighed og om jorden som det sted, hvor mennesket møder "alles Schöne und Wahre" (Herder 1782/1993, 709). 
Grundtvig mener, må være et blandingsfolk (524), ${ }^{30}$ dels i en redegørelse for, at syrerne må være Abrahams slægtning Labans efterkommere:

Skriften lærer os, at Laban førde Hyrdeliv, men det er at den ligesaa aabenbart, at der ret egentlig var en Kræmmeraand i ham, og vi kan ei tænke os nogen dueligere end hans Afkom til at bebygge Palmyra, dette Karavanernes Hvilestæd mellem Babylon og Phønikien, hvor man kunde vinde favre Guldsmykker ved at give Kameler Herberge, og faae rige Morgengaver for sine Døttre (372).

I overensstemmelse med krønikens overordnede teori om en urmonoteistisk religion i menneskeheden bestemt af paradislivet - og her i særdeleshed semitternes tro - har syrerne ifølge Grundtvig oprindeligt kendt til den sande gudsdyrkelse. Men som en følge af, at "en Kromand" - og en sådan ligner det personificerede syriske folk ifølge Grundtvig - "søger at giøre alle sine rige Gæster tilpas" (375), har de imidlertid hengivet sig til polyteistisk tilbedelse af andre folkeslags guder.

I Til Fedrenelandet om dets Tarv og Fare var beskyldningerne om kræmmerånden rettet mod jøderne. Det er derfor nærliggende at spørge, hvorfor Grundtvig gennem hele sin afstamningslære i 1814-krøniken ikke knytter kræmmerånden direkte til Israel? Årsagen er formentlig ikke, at Grundtvig har skiftet synspunkt, men at anklagen mod jøderne for griskhed for ham at se først giver mening efter år 70. Dette kunne, skal man følge tankegangen, lade sig gøre, fordi handelslivet og dermed begærligheden efter

30 Den uvilje mod folkeblandinger (Vind 1999, 467), som Ole Vind tidsfæstner til 1815 med Grundtvigs skrift Europa, Frankrig og Napoleon. En dansk historisk Betragtning, er altså allerede til stede i VK 1814. Fønikerne er "en Blanding", en "Forening af trende Stammer" (VK 1814, 533), derfor er de delt i henseende til næringsveje og "Tvende herskende Tilbøieligheder som ere tvertimod hinanden er hos én Stamme som hos eet Menneske en Uting" (503). "Deler" et "forenet Folk" sig mellem "to Haandteringer", kan "Folkets Undergang" alene forhindres af "dem, der pløie Marken eller Havet", altså landmænd og sømænd, eller ved "de Fremmede et saadant Folk gierne optager i sit Skiød, og stjæler Livskraften fra” (530). 
jordisk guld og sølv ligger som en latent mulighed hos alle Sems ætlinge og dermed også hos jøderne. ${ }^{31}$

At jødernes tilbøjelighed fra begyndelsen overvejende er rettet mod det hyrdeliv, som for Grundtvig udgør den højeste livsform, hænger sammen med, at Israel er den vigtigste nation blandt folkeslagene. Hos jøderne møder man den højeste form for menneskelighed, det alenmål, hvormed alle andre nationer skal måles. Det skyldes Israels status som et semitisk "Digterfolk" (290; 291), "det mest poetiske Folk" (210) i menneskeslægten. Som i $V K 1812$ (VK1812, 212) sidestiller 1814-krøniken "Digtere” og "Propheter". De er "Seere og Sangere tillige" (328), og et jødisk individ er i besiddelse af "digterisk Natur" og har derfor lettere ved at "tilegne" sig "fremmede Tungemaal" (365) end andre.

Grundtvigs billede af det hebraiske sprog støtter sig - uden at det fremgår af verdenskrønikens ellers udførlige noteapparat - på dette punkt til Herders karakteristik af det jødiske folk som poetisk og bestemmelsen af verbet som handling i Vom Geist der Ebräischen Poesie. "Grundsproget", menneskehedens paradisiske ursprog, dominereres af "Roden" (191). I dette fandtes kun "Verber og Substantiver" (192), og "i det Ebraiske Sprog" ses "kiendelige Levninger" (190 f.) heraf. På hebraisk er "al Tale (...) Vers, al Røst Sang, som det hos de første Mennesker maatte være” (195).

Det Herder-inspirerede billede af det jødiske folk som et åndens og dermed poesiens folk glider i krøniken ikke sammen med Fichtes tanker om det tyske folk som et urfolk, men derimod med Fichtes begreb om normalfolket. Micha Brumliks iagttagelse af, at Fichte overfører det gammeltestamentlige udvælgelsesmotiv på det tyske folk, er ikke i første række den ramme, Grundtvigs tanker om udvælgelse skal fortolkes ud fra. Det folk, der for Grundtvig på ideel vis virkeliggør en nations natur, er netop det jødiske:

\footnotetext{
31 At både negative og positive billeder af jøderne optræder i Grundtvigs tekster, kunne tages som et argument for, at begge dele er udtryk for en bestræbelse på at tildele og fastholde jøderne i rollen som fremmede i forhold til det øvrige samfund. En sådan tolkning - ikke af Grundtvig, men af samtidige forfattere i perioden - gennemfører Kristoffer Kjærgaard i sin klare og teoristærke Foucaultinspirerede ph.d.-afhandling, Opfindelsen af jodiskhed, 1813-1849. Semitisk diskurs og produktionen af jodiskhed som andethed, Roskilde Universitetscenter 2013.
} 
For dem der have Forstand paa de Love efter hvilke Mennesket udvikler sig, vil jeg end bemærke, hvad Bogen tydeligere udvikler, at, ligesom Man i et Folks Poesie see dets høieste Flugt og saaledes den Aandelighed, hvortil det i sig selv kan udvikles, saaledes maa vi i det mest poetiske Folks Poesie, see Menneskeslægtens høieste Flugt, er da Jøderne det mest poetiske Folk, maatte Menneskeslægtens Maal, saavidt det for den var beskueligt, staa afbildet i Jødernes Poesie, og Slægtens Gang i deres Historie, om saa intet Overnaturligt var i dem, vi maatte alligevel i Jøderne see det Normalfolk, om hvilket Fichte drømde (XXIV).

Ved at angive, at Fichte drømte, markerer Grundtvig, at Fichtes forestilling om normalfolket er en tankemæssig, kontrafaktisk konstruktion. I det jødiske folk har drømmen for Grundtvig at se så at sige fåt kød og blod, idet hebræerne som nation er overlegen i forhold til alle andre nationer. "Christi Folk maa være det ypperste" ved, at han selv har givet dette folk "Vidnesbyrd" (XIX). Menneskeheden er blevet "ful kommen" (sic!), når den er som Jesus af Nazareth. Når mennesker i dag ikke stræber efter at nå dette mål, skyldes det, at de ikke ønsker at nå det på den måde, "Normalfolket foreskriver" (XXV). Kristi menneskelighed er for Grundtvig jødisk - og dermed bestemt af indbildningskraftens styrke hos Israels folk. ${ }^{32}$

32 Ole Vind har i Grundtvigs historiefilosofi talt for, at "Fichtes Reden er en helt afgørende forudsætning for hele den videre udvikling i Grundtvigs historiesyn efter 1814" (Vind 1999, 118). Vind fremhæver, at "hovedargumentet" i Grundtvigs skrift Europa, Frankrig og Napoleon fra 1815 "følger Fichtes Reden: tegnet på, at netop Danmark er udvalgt, finder Grundtvig i Danmarks egenartede og lykkelige historie" (Vind 1999, 121). Danmark har dermed bevaret sin folkekarakter og sit sprog rent uden påvirkninger fra fremmede folkeslag. Vind forbigår imidlertid det faktum, at Grundtvig eksplicit bruger begrebet om normalfolket om det jødiske og ikke bestemmer det danske, men det jødiske folk som idealfolket. Vind omtaler heller ikke, at Grundtvig gentager karakteristikken af "Ebræerne" som "NormalFolket" (US V, 423) i Nordens Mythologi fra 1832, et skrift, som ellers spiller en hovedrolle i hans afhandling. Helge Grell gør i Skaberånd og folkeånd. En undersogelse af Grundtvigs tanker om folk og folkelighed og deres forhold til hans kristendomssyn rede for, hvorledes Fichte omtaler "1. Mosebog som myten om "normalfolkets" og dets religions spredning blandt folkene" (Grell 1988, 49). Grell fremhæver i modsætning til Vind ganske korrekt, at det jødiske folk for Grundtvig er "det normalfolk" (Grell 1988, 98), Fichte drømte om, og dermed det folk, der giver den ideale nation jordisk skikkelse. 


\section{Normalfolket som forbillede for styreformerne i historien}

Verdenskrønikens billede af Israel som et poetisk digterfolk hænger som sagt også sammen med Grundvigs idealbillede af, hvad han betegner "Stat (...) Samfund (...) og Øvrighed” (249). For at forstå den fulde rækkevidde af idealbilledet er det nødvendigt at gøre sig bekendt med Grundtvigs teologisk-filosofiske verdensbillede i 1810'erne. Beskrivelsen af samfundsinstitutionerne hænger nemlig for Grundtvig sammen med den "systematik" (Prenter 1983, 70), dvs. det billede af Guds trinitariske væren i de menneskelige bevidsthedsevner, der holder Grundtvigs "livs- og kristendomssyn" (Prenter 1983, 71) sammen. ${ }^{33}$

Til de tre personer i Gud svarer en trichotomisk inddeling af mennesket $\mathrm{i}$ ånd, legeme og sjæl, som igen korresponderer med bevidsthedsevnerne indbildningskraft, følelse og forstand/fornuft og sanserne syn, følelse og hørelse. Grundtvigs historiesyn er struktureret ud fra bevidsthedsevnernes successive dominans fra indbildningskraftens alder over følelsens tid frem til forstandens og fornuftens periode, hvor en bearbejdelse af de primære bevidsthedsevners informationer fra de første historiske perioder finder sted. At hver periode har grundlag i mennesket, som det kom fra Guds hånd i paradiset, betyder, at tre-fase-skemaet så at sige er bøjningsmønster for menneskehedens og i særdeleshed det jødiske normalfolks historie. Som Grundtvig anfører: "Det skal siden sees, hvorledes denne Gang giver sig tilkiende hos Hedningene midt i den Forvirring som maa ventes, men her skal det betragtes, hvordan Gud afbildede det Sande hos sit Folk" (252).

Bøjningsmønstret går her, som det nedenfor vil fremgå, også ind i beskrivelsen af idealfolkets samfund. Det viser sig bl.a. at være baggrunden for et forsvar for teokratiet i Det Gamle Testamente. Som indledning til sin redegørelse for, hvorledes treledsfasen kan genfindes i Israels historie, beskriver Grundtvig samtidens "daarlige Tale om Theocratiet (Guds Regiering) som en jammerlig Forfatning", således som det er tilfældet i Moses

33 Villiam Grønbæk har i Psykologiske Tanker og Teorier hos Grundtvig samlet en række markante tekstsammenhænge, hvori Grundtvig gør rede for bevidsthedsevnerne. Grønbæks bestræbelser på at fremhæve den bibelske inspiration og originaliteten i Grundtvigs tankeverden får ham dog til at underbetone indflydelsen fra psykologien hos filosoffen Christian Wolff (1679-1754) i forfatterskabet (Grønbæk 1951, 71). 
og Jesus eller om Jødernes og de Christnes intellectuelle og moralske Forhold (Buchholz 1813). Men for Grundtvig er den mosaiske "Lovgivning" ikke som hos Buchholz præget af grusomhed og hårdhed. Den har derimod givet det jødiske samfundsliv "Eenhed og et høiere Sving" (378) i forhold til Israels semitiske naboer og slægtninge. "Lovene" i den jødiske stat var nemlig ikke "læmpede efter Folkets eget Tykke" (263), og dog var de ikke kun hårde, men var på en gang både "stræng[e]" og "barmhjertig[e]" (264). Grundtvig anser med slet skjult hentydning til Buchholz sin samtids modstand mod teokratiet for at være et udslag af det vantro menneskes ønske om at "raade sig selv". Enhver “ædru Mand” må indrømme, "At Gud regierer", men han gør det på forskellige måder, "efter Folks og Tiders Vilkaar" (252). Guds særlige hensigt med udvælgelsen og opretholdelsen af det jødiske folk lader sig udlede af Israels historie:

Det Særsyn er da, som saamange, kun forklarligt, naar Man antager at Folkets hele Historie er Sandhed, thi da forstaaes det lettelig. Ligefra den Dag Gud udførde Abraham af hans Fædreneland havde Slægten og Folket vandret og boet imellem Fremmede, hvis Sprog, Sæder og Vilkaar i det Hele vare aldeles forskiellige fra deres, og i Canaan vare de ei blot omringede af Fremmede og Fiender, men indviklede iblandt dem, havde da ogsaa Fælledskabet under Ægypti Aag, paa den lange Vandring i Ørken og ved Canaans Erobring været glemt og den fælleds Gudsdyrkelse og Lovgivning foragtet, Sammenhold og Følelse af giensidig Trang til hinanden maatte dog vedblevet, dersom Stammerne ei ligegyldig vilde seet paa deres egen Ødelæggelse (321 f.).

Ud over at pege på, at jødernes minoritetstilværelse allerede blev indledt i gammeltestamentlig tid, sigter Grundtvig mod at vise, at det guddommelige forsyn bevirker, at det jødiske folks sammenhold skulle styrkes gennem et ydre pres. Hvor Buchholz alene lader Gudsfrygten skabe sammenhold, er der for Grundtvig tale om en indre drift, et ønske om overlevelse hos det jødiske folk. Derved siges det implicit, at det jødiske folks status som normalfolk betyder, at andre nationer såvel som den kristne menighed skal præges af et sådant sammenhold.

Accepten af Guds forsyn som bestemmende for tidernes gang har i kirkehistoriens løb givet den kristne menighed respekt for teokratiet i det gammeltestamentlige Israel, mener Grundtvig. Det bør den også fort- 
løbende gøre. Historien viser således, at "alle Christne [have] agtet den Forfatning [som Gud] gav sit Folk, for ypperlig i alle Maader, enddog de ei udgrundede dens Viisdom" (252 f.). Dertil kommer, at "ogsaa de Folkefærd, som "jøderne have været Udlændinge hos og for hvem de have været en Spot og Forhaanelse, have bøiet sig ærbødig for deres Prophetes Ord”, hvilket vil sige, at Moses også blandt disse tillægges profetstatus. Til disse folkefærd regnes også det danske folk. Derfor må al afstandtagen fra den jødiske lovgivning ses som et frafald i forhold til den ærbødighed for Moses' lov, man ifølge Grundtvig kunne møde i hans barndom hos "Barn og Bonde" (180). Grundtvig indlægger derved implicit en klar kritik af såvel Møllers teologiske antijudaisme som den litterære fejdes jødefjendtlighed. I "1700 Aar" har "gudfrygtige Mænd" (180) siddet ved den jødiske lovgivers fødder, fremføres det. ${ }^{34}$

Da krøniken når til Josvas $\mathrm{d} ø \mathrm{~d}$, introduceres statsbegrebet ved en annoncering af en gennemgang af "den Skikkelse som Staten havde i Begyndelsen hos Israel” (249). Grundtvig fremhæver, at Israels statshistorie i virkelighed kun kan forstås med menneskets oprindelige status i paradiset som baggrund, da det "er vist, at Herren efter Faldet ei skabde noget Nyt paa Jorden uden Jesus Christus som Mennee (sic!)”. Hovedpointen er, at "Alt" på jorden, der tjener til Jesu "Herliggiørelse", dvs. alt, hvad Jesu påtog sig af sand menneskelighed i denne verden, "tjener (...) Menneskets Udvikling” (249), både som den var bestemt før faldet, og som den går videre før og efter Kristus.

Netop her begynder det treledede bøjningsmønster at blive tydeligt. Den sande menneskelighed er efter Evas brøde "et sønderrevet og fordunklet Billede af Noget, som hørte til Menneskets Kaar" (249). ${ }^{35}$ Grundtvig gør i denne sammenhæng opmærksom på, at "Samfund" og "Øvrighed" ikke blot, som det betones hos Luther og i den lutherske tradition, er nødvendige for "at hindre Overtrædelse", men at de også har betydning for, "at et fælleds Maal kan naaes og hver Enkelt vorde skikket til den Gierning, som er hans". At menneskene både skulle være "Enkelte" (249), dvs. individer,

${ }^{34}$ Med andre ord har den gammeltestamentlige lovgivning, sådan som det er Guds mening, inspireret staternes regelsæt i kristenheden - og, kan man føje til, i de lutherske kirker med afsæt i toregimentelæren.

35 Sammenstillingen af substantiverne "Menneske" og "Vilkaar" virker ned gennem værket som en form for signalering af filosofiske overvejelser (f.eks. VK 1814, IV, XXIII, XXVII, 13, 34, 143, 210, 249, 250, 253). 
og samtidig "forenede til et fælleds Værk" (249 f.) begrundes tidstypisk ud fra tanken om, at delene i en levende organisme alene skal forstås ud fra helheden og lovene for dens udvikling. De enkelte dele skulle være "indvortes adskillige og hinandens Udfyldning”. De forskellige individer såvel som menneskeheden "skulde fødes som Børn og derefter voxe" i overensstemmelse med den trichotomiske antropologi: "Aanden saae det Billede, som Hjertet skulde forenes med i Kiærlighed og Sjælen lære at forstaae" (250). Der er altså tale om en proces, hvor Guds billede af det rette samfundsliv i indbildningskraftens fase kommer til mennesket gennem en vision, for derefter i følelsens epoke at blive accepteret og omsluttet af menneskets kærlighed. I den tredje og sidste fase indser mennesket med sin fornuft, at den samfundsstruktur, Gud har ønsket, er den rette. "Hjertet" indtager her legemets plads, men der er tale om en glidning i tankegangen, idet kærligheden som knyttet til følelsen lader bevidsthedsevnerne indbildningskraft, følelse og forstand/fornuft glimte frem i teksten.

Det, man sidenhen har kaldt en "Stat", er en "ufuldkommen" afbildning af det paradisiske samfund. Øvrigheden er i paradiset, men også siden hen “først (...) prophetisk og præstelig”. Det betyder, at "Indbildningskraften" som "den fornemste Deel” (251) af bevidsthedsevnerne råder. I paradiset var profeten, dvs. den med "det klareste Øie" "Veiviser" og "Øvrighed". Profetens hovedopgave var at fordele arbejdet mellem "sine Brødre", en ordning, Grundtvig som Luther forbinder med husstanden under husfaderens styre. Det patriarkalske husliv kan altså spores tilbage til paradiset, hvor det skulle "afpræge[s]" hos "hver Fader i sit Huus". Man aner tydeligt Luthers Genesiskommentar, som Grundtvig også nævner flere gange i $V K$ 1814 som baggrund i denne sammenhæng. ${ }^{36}$

\footnotetext{
36 Således citerer Grundtvig, med tilslutning Luthers bemærkninger i Genesiskommentaren om Sems efterkommere ordene om, at dette "Kapitel", der har voldt "lærde Mænd" bryderier, "ret skal lære os vor store Vankundighed" (59). Han fremhæver videre, at "det er med al Forklaring, som Morten Luther siger om Allegorien", at "den er et Luftspring, naar den ei hviler paa Historien" (VK 1814, 14). Grundtvig henviser dermed til det sted i Genesiskommentaren, hvor Luther udtrykker sit ubehag ved enhver allegorisk fortolkning og priser "der historische Verstand" (Luther, 1835-45/1880, 285). For Grundtvig legitimerer Luthers udtalelse formodentlig hans virke som historiker og den udhævede plads, historien har i hans forfatterskab.
} 
Det overraskende er, at Grundtvig i 1814-krøniken udbygger Luthers udlægning af begrundelsen for det verdslige regimentes rod i forældreembedet med sin syvmenighedstanke og på den baggrund maler husstandsmotivet i endnu lysere farver end denne. ${ }^{37}$ Husstanden spejler som et mikrokosmos "det ganske Samfund". Med det som forudsætning kan Grundtvig etablere en trinrække fra husstanden over nationen til menneskeheden som helhed, dvs. den overordnede, samlende organisme:

Vidste man (...) i hvor mange Hovedretninger Aanden skuer og Mennesket skal udvikles, da vidste Man og hvor mange Stater der i Paradis kunde været, i det en stor Prophet stod i Spidsen for hver Menighed, som ved nærmere aandeligt Frændskab havde ligest Hovedretning, medens Adam stod med et Syn, hvori Alt igien forenedes, og som det synlige Vidne om, at alle Menneskens Børn vare komne af det ene Menneske og skulde kun udvikles til i vitterlig Kiærlighed at vorde Eet i Guds Billede, i Sønnen, hvis Legeme de vare (250).

Tanken er, at der i paradiset - hvis ikke syndefaldet var kommet imellem - ville have været "syv" hovedretninger i menneskeheden. Grundtvig arbejder altså i denne sammenhæng med et skabelsesgivet fundament for menneskeslægtens udvikling, der, hvad forskningen ikke tidligere har bemærket, udgør den form, hvori kirkehistoriens syv menigheder siden hen bliver støbt. De syv hovedretninger ville i paradiset have udviklet sig blandt efterkommerne af det første menneskepar og udgjort basis for syv nationer, folkeslag, der samtidig var menigheder. Begrundelsen for, at der skulle være syv i tal, gives med tydelige allusioner til Åbenbaringsbogen (Johs Åb 4,5; 1,12; 1,16; 5,6):

at der stande syv Aander for Guds Throne, der ere som brændende Lamper, ja at de syv Stjerner, som Johannes saae, ere de syv Menigheders Engle, at Lammets syv Horn og syv Øine ere de syv Menigheders Engle, at Lammets syv Horn og syv Øine ere de syv Guds Aander, som ere udsendte til al Jorden (251).

\footnotetext{
37 Når Grundtvig år senere i Krønike-Riim lader paradiset sige om sig selv, at mennesket kan se "Glimt" af dets "Yndighed (...) i Aftenrøden og Hjemmets Fred" (Grundtvig, 1929/1875, 2), kan der altså være tale om en refleks af Lutherpåvirkningen i $V K 1814$.
} 
Resultatet er, at "Christi Menighed viser os Skikkelsen af den" menighed, "som det ufaldne Menneske skulde ligefrem afbildet", og "disse syv Menigheder" i paradiset "skulde fulgt efter hinanden, og dog efterhaanden blevet samtidige" i kraft af den udødelighed, der hørte paradiset til. Syvmenighedsmotivet fungerer på denne måde i den refererede sammenhæng som et led i Grundtvigs redegørelse for styreformer og statssamfund.

\section{4-krønikens syn på samfundets udvikling}

Grundtvigs billede af samfundsudviklingen i paradiset og i historien er i et videre perspektiv et led i tanken i $V K 1814 \mathrm{om}$, at samtiden har privilegeret indsigt i historiens gang, Guds "Husholdning" (251), en indsigt, man må formode, Grundtvig har et særligt blik for. Menighederne i paradis ville efter deres bestemmelse have gennemløbet et trefaset udviklingsforløb, mener han, der svarer til den i dag almindelige tredeling af historien i oldtid, middelalder og nyere tid. Epokerne domineres af de menneskelige bevidsthedsevner på skift og betegnes som henholdsvis "Indbildningskraftens Alder" (49), der er "Heltetiden", "Riddertid[en]" (341) og den tid, hvor "Erkiendelse" (15) og "Eftertanke" (253) dominerer. Disse perioder ligger bag samfundsudviklingen også efter syndefaldet, om end med de brud og fejludviklinger, det har afstedkommet. I det jødiske folk - Guds ejendomsfolk og til trods for synden normalfolket - kommer den paradisiske udvikling klarest til udtryk. Hos "Guds Folk" måtte den paradisiske "Indretning komme tilsyne i sin hele Reenhed", kun let ændret af "Faldet" (253). Dette afspejler sig i patriarkerne, som var præster og profeter:

Under Paulunerne lod Gud Israel udvoxe af en fælleds Rod, én Prophet kunde ikke altid leve, eftersom Døden var kommen i Verden, men Abraham, Isak og Jakob staa dog som uadskillelige for os, ligesom for Ham der kalder sig deres Navns Gud, og beskue vi de tre Stammefædre ret, finde vi dem og at være Afbildninger af og Forbilleder paa de trende Hovedting: Syn og Kiærlighed og Eftertanke (253).

I de sidstnævnte fænomener møder man de tre nævnte bevidsthedsevner, og hver af de gammeltestamentlige patriarker er altså typologisk forbillede for de kommende perioder. 


\section{Samfundslivet $i$ indbildningskraftens epoke}

I den første periode, indbildningskraftens tid, adlyder såvel digterprofeten som statssamfundets undersåtter i paradiset blindt det, som gives dem gennem åndens åbenbaring. Gud meddeler sig simpelthen gennem indbildningskraftens syner, og ligesom "Vejviseren maatte tro sit Syn, enddog han ikke forstod det, saaledes maatte de, der ei saae det saa klart, tro hans Ord enddog de tykdes underlige, af dyb Ærbødighed for hans hemmelige Samfund med den ene Vise: Gud" (251). Indbildningskraftens tid er således tiden for absolut lydighed i tro, skønt hverken "Vejviseren" eller de undersåtter, der i paradiset anvises vejen, forstår det "Syn"(251), som Gud har givet.

Det samme mønster kan efter uddrivelsen af paradis iagttages i "Semiternes Oldtid", dvs. hos Sems efterkommere i den første tidsalder af deres historie. I de semitiske folkeslags oldtid, siger Grundtvig med en tydelig samtidspolitisk allusion, er "Indbildningskraften (...) saa at sige, enevældig" (383f.). Men forestillingsevnens tvingende kraft bevirker, at styreformen hos de ikke-jødiske semitter tager skikkelse af et despoti. Grundtvig konstaterer, at man ikke ved i detaljer, hvordan Gud "har beskikket det iblandt" israelitterne, da de med "de tolv Patriarcher" udviklede sig "til et Folk" (253). Men - som et tydeligt modbillede til Buchholz, der som bekendt udlægger udlændigheden i Ægypten som Faraos forsøg på at lære jøderne nyttigt fysisk arbejde - hævder Grundtvig, at det var forsynets vilje, at de en tid skulle under fremmed herredømme. Da der "bleve flere" rivaliserende "Stammefædre ved hinandens Side", måtte jøderne styres af ægypterne, idet herrefolkets ydre tryk da skabte indre sammenhold hos de undertvungne. Ved at skulle adlyde ægypterne "vænnedes" jøderne med tiden "til Lydighed mod Love", de "ei kunde udgrunde" og "til Ærbødighed for Guddommens hemmelige Tjeneste" (254).

Denne lydighed førtes videre i den efterfølgende udvandring til ørkenen, som Grundtvig betragter som overgangen fra indbildningskraftens til følelsens tid. Moses og loven tilhører således tiden for "Israels Helteliv" (339). Her var “Ærbødigheden for Moses’ Tale i Herrens Navn, Troen pa Hans Samfund med Gud, og Villien at lyde, (...) det eneste Baand, der sammenknyttede Stammerne" (255). Moses var derfor som profeterne i paradiset leder og som sådan den, der formidlede Guds vilje, al den stund Gud var den egentlige regent. Moses ledelse af folket under ørkenvan- 
dringen er derfor et forbillede på, at Israel siden hen skal have en øvrighed i form af en konge, men dette sker først, da Israel er nået ind i følelsens epoke.

\section{Samfundslivet i folelsens epoke}

Det følger af logikken, at samfundet i paradiset aldrig når ind i følelsens og kærlighedens tid. Grundtvig afstår imidlertid ikke fra i kort form at beskrive, hvordan epoken ville have forløbet i Edens Have: "Alt som nu Tiden gik, udvikledes Propheten og de Andre med, Kiærligheden voxde i Fornemmelsen af Herrens Godhed, og af Synets Sandhed, og da var $\emptyset_{\mathrm{v}-}$ righeden blevet kongelig" (251). Den paradisiske profet og hans menighed lyder i følelsens tid ikke længere blot Guds vilje blindt, men følger de guddommelige bud gennem følelsen som fornemmelse eller dunkel forståelse. I overensstemmelse med udviklingslovene bliver profeten derfor til konge, og et kongedømme er for Grundtvig karakteriseret ved, at folket er følelsesmæssigt knyttet til ham og derigennem til Gud, hvis budskaber kongen videregiver.

Dette præfigurerer, hvordan Israels folk udvikler sig. Allerede under ørkenvandringen er der som antydet tale om, at den profetisk-præstelige regeringsmagt, det "Theocratie", som Moses formidler, udvikler sig til et kærlighedens kongedømme ved “Ærbødigheden for Moses' Tale i Herrens Navn”. Det afgørende bliver, at netop viljen til at adlyde for Grundtvig er følelsens epokes bevidsthedsform og dermed det led, der forbinder det profetisk-præstelige styre med det kongelige: ${ }^{38}$

Villien at lyde, var (...) det eneste Baand, der sammenknyttede Stammerne, og ligesom Enden paa Budet var Kiærlighed, saaledes skulde og Israel ved at holde Budene og erfare deres Velsignelse indvortes og udvortes, lære at elske dem, og saaledes være beredt til at hilse og annamme den himmelske Konge, naar Han nedsteeg at opreise Sin Throne paa Jorden (255 f.).

38 Grundtvig forbinder viljen med følelsen. Sammenhængen supplerer og korrigerer Grønbæk, når han skriver, at han ikke har fundet noget sted i Grundtvigs forfatterskab, hvor han "forsøger at indordne viljen under sin inddeling af sjælelivet” (Grønbæk 1951, 106), dvs. treklangen indbildningskraft, følelse og forstand. 
Tanken om religionens sammenbindende kraft deler Grundtvig med Buchholz, men i modsætning til billedet af frygt som den sammenbindende faktor peger Grundtvig altså på kærlighedsbåndet som det væsentlige. Gennem de fyrre års ørkenvandring under Moses’ ledelse udvikler teokratiet sig således i kærlighedens alder til kongedømme. I paradiset var det meningen, at Kristi kongedømme skulle afløse indbildningskraftens poetiske og præstelige tid og Guds direkte regentskab i forbindelse med sønnens nedstigen "paa Jorden” (325). Sådan gik det imidlertid ikke. Gud måtte etablere en ydre, synlig kongeinstitution, dvs. gennem Samuel salve en konge, fordi "Israeliterne" var "gienstridige mod Herrens Mund (...) i alle Medgangs Dage" (325). Israels folk er, som det eksempelvis skildres i 2 Mos 32,9, "et haardnakket Folk" (173). Derfor gælder, at hvis jøderne skulle "blive i Landet", dvs. det forjættede land, "maatte gudelige Hænder tvinge dem" (325). Som Buchholz er Grundtvig bevidst om magtudøvelsen i forbindelse med etableringen af den jødiske stat, men peger i modsætning til ham på det positive $\mathrm{i}$ kongens tvang. Der er ikke tale om en vilkårlig og brutal undertrykkelse. Israels konge er ikke lammet i sine handlinger, han er en magtfuld og effektiv regent, men samtidig bindes han kontraktligt til at følge Moseloven,

Baggrunden for det magtfulde, men regulerede kongedømme er, at "Jehovah”, som det var tilfældet under ørkenvandringen, også nu er den rette konge for israelitterne. I den paradisiske idealtilstand ville poetprofeten have udviklet sig til konge, men da på Guds vegne. Den profetiske konge ville uden videre have adlydt Gud, og derfor var det ikke nødvendigt med en lov, der regulerede kongemagten. Så frit kan Israels konge ifølge Grundtvigs ræsonnement ikke stilles. Inspireret af det deuteronomistiske historieværks skepsis over for kongeinstitutionen, herunder kongeloven i 5 Mos 17, hævder han, at det kongedømme, som opstod i Israel med profeten Samuels salvelse af Saul (1 Sam 8-10), blev til som en følge af, at israelitterne ville "være som Hedningene" (316). Det var derfor egentlig en "ond (...) Gierning" at Israel begærede "en Konge" (319). Til trods for det bliver kongedømmet dog stadig til efter Guds vilje. Kongen er konge på Guds vegne, og både han og folket skal "frygte Jehovah og tjene Ham" (319).

Men yderst bemærkelsesværdigt noterer Grundtvig også, at det var Guds vilje, at kongen havde en profet ved sin side, der kunne give "Undervisning i Guds Lov". Følgelig "sad da Saul paa Israels Throne og Samuel 
stod ved hans Side som Jehovahs Mund, og hvert Ord af ham maatte Kongen lyde, om han vilde frygte Gud og fare vel” (328 f.). Bag denne rollefordeling aner man den mosaiske lovgivning som inspiration i de lutherske stater, ligesom man får et billede af, hvorledes Grundtvig tænker sig rollefordelingen mellem det verdslige og gejstlige regimente i disse stater. Kongen bærer lovens sværd, men vejledes i sin styrelse af det gejstlige regimentes præsteskab.

Det fremgår imidlertid også af teksten i $V K 1814$, at Grundtvig arbejder med afgørende forskelle på det semitiske Israel og de jafetidiske europæiske folkeslag, hvor den lutherske reformation blev gennemført. Disse forskelle kommer til udtryk i måden, hvorpå kongedømmerne blev etableret i oldtiden blandt henholdsvis semitter og jafetider. Hos semitterne var der tale om despotisk enevælde, hos jafetiderne er der tale om gensidig kærlighed mellem konge og folk. Den lutherske implementering af det gammeltestamentlige kongedømme farves ifølge Grundtvig af jafetidernes disposition for kærlighed. Men i denne sammenhæng bliver den jødiske historie et korrektiv til de herskende teorier om kongedømmet. Grundtvig sigter her muligvis til samtidens kontraktteoretiske overvejelser i forlængelse af den engelske filosof Thomas Hobbes (1588-1679), der arbejdede med kongens kontraktligt sikrede "absolutte enevælde" (Sløk 1962, 251). Grundtvig gør sig i modsætning hertil til fortaler for at begrænse kongemagten og peger i den forbindelse netop på dens oprindelige forskellighed hos jøderne, de øvrige semitter og jafetiderne:

Mærkelig adskiller sig denne sandfærdige Fortælling om Kongedømmets Oprindelse i Israel fra hvad Man pleier at giætte om Maaden, hvorpaa Jorderigs Throner ere opreiste, og enddog den Adskillighed for en Deel kommer deraf, at Giætningerne vare falske, er det og unægtelig at den hele Begivenhed var et uforklarligt Vidunder, naar vi ikke kiendte Israeliternes mageløse Vilkaar. Det er anmærket, at Kongedømmet i sin rette Skikkelse maa være Kiærligheds Frugt, og det er vist, at den er kun til der, hvor Kongen føler sin Eenhed med Folket, og Folket sin med ham og med hinanden. Det er da i sin Orden, at vi hos Folkene af Japhets Stamme finde et Slags patriarchalske Konger ved deres Krønikes Begyndelse, men det er og i sin Orden, at vi hos Semitterne finde det anderledes, at, hvor det undtes dem, adskilte de sig i ligesaamange Stammer, som Slægterne bleve, de forenedes end ikke ved fælleds Guds- 
dyrkelse men kun ved legemlig Tvang, og hvor vi finde Konger hos dem, finde vi ogsaa uindskrænkede, høitbydende Herrer, Despoter. Denne Bemærkning, som hviler urokkelig paa den hele bekiendte Krønike, lærer os at beundre Guds Husholdning med Israel, som Han vidste at forene, men ogsaa at forundre os over Israels Lyst til en Konge, som yttrede sig alt i Gideons Dage, og det, uagtet Folkets Adfærd i Moses, ja i Dommernes og Kongernes Dage tilstrækkelig kundgiør deres Lighed med Frænderne i dette Stykke (320f.).

At der med Israel er tale om et "uforklarligt Vidunder", viser, at historien aflægger vidnesbyrd om den guddommelige underfulde udvælgelse af "Normalfolket". Grundtvig betragter normalfolket som en slags korrektiv for al eftertid. Gud har gennem sin "Husholdning" udvalgt og udsondret Abrahams slægt med det formål i begyndelsen selv at være Israels konge og siden hen skabe et kongedømme, der afveg fra den almindelige semitiske enevælde:

Læse vi nu i Mose Lov Budet om Kongen (5. Moseb. 17) og den Anmærkning (1. Sam. 10) at Samuel sagde Folket Rigens Ret og skrev den i en Bog, da see vi hos dette Folk, hvad vi allermindst skulde vente: Grundtrækkene af det rette Kongedømme, frivillig Valg, og Indskrænkning ved en Grundlov (321).

Rekonstruerer man Grundtvigs tankegang, træder hans politiske ideal frem på en overraskende måde. I det jafetidiske Danmark har det gældende arvekongedømme og kongens suverænitet i en periode været den rette styreform, den samfundsordning, der var i overensstemmelse med følelsens dominans hos Jafets efterkommere. Med ovenstående karakteristik af europæernes kongedømmer som "patriarchalske" (320f.) og derfor præget af ærbødig kærlighed fra folkets side tilbageskriver Grundtvig i overensstemmelse hermed det lutherske husstandsideal til oldtiden, hvor monarkierne er blevet til. Men det patriarkalske enevælde skal ikke være gældende i Europa til evig tid. Der er nemlig noget at lære af det jødiske samfund i gammeltestamentlig tid, fordi man hos "Normalfolket" møder en mere ideel styreform: det ved lovgivning indskrænkede valgkongedømme. 
Igen hænger tankegangen sammen med, at jøderne befinder sig tættere på paradiset. Hos jøderne i oldtiden kan man således iagttage de samme fænomener, som forekom under de ideale, paradisiske styreformer, men nu i en jordisk skikkelse, dvs. med syndefaldet som baggrund. Her var gensidighedsforholdet mellem konge og folk som bekendt en følge af, at følelsen i overensstemmelse med menneskets skabelse er den bærende bevidsthedsevne i den jødiske histories anden epoke, men at dette også er planlagt sådan af det guddommelige forsyn. Moseloven er Guds åbenbarede vilje med Israel. Når det jødiske folk derfor i historien om Sauls udvælgelse arbejdede med tanken om "at indskrænke Kongen” gennem lovgivningen, var det derfor i virkeligheden ikke folkets eget påhit:

aldrig havde det Folk tænkt paa at indskrænke Kongen, ligesom vi da veed, at en saadan Eftertænksomhed var tvertimod de Semitiske Folks Beskaffenhed i gamle Dage, som end mod Digterens, men at Gud ei vilde, at Kongen skulde være lovløs, det kan Man vide og derfor skrev hans Prophet Kongeloven (323).

Det, Grundtvig her tænker på, er, at ligesom digtere er underlagt indbildningskraftens begejstrede inspiration, således bemægtiger indbildningskraften sig semitternes bevidsthed og kræver betingelsesløs underkastelse. Denne blindt troende lydighed skabte hos de semitiske israelitter et rum for magtmisbrug, og for at forhindre det blev den jødiske kongelov til (5 Mos 17,14-20).

Sammenligningen i det lange ovenstående citat med de jafetidiske patriarkalske kongedømmer (320 f.) sandsynliggør, at Grundtvig med "Kongeloven” samtidig alluderer til den danske enevældelovgivning fra 1665. Baggrunden er, at Grundtvig arbejder med en usædvanlig forbindelse mellem oldtidens jøder og samtidens europæere. Forbindelsen eller ligheden, der binder dem sammen, er følelsen. Jøderne var i kongetiden nået ind i følelsens epoke, og Grundtvig kan genfinde de danske undersåtters "inderlige devotion og kierlighed" og "Hiertelig[e] Attraa" til kongen her. Dette korresponderer med, at følelsen hos de europæiske jafetider er det fremtrædende karakteristikum, og i særdeleshed i det danske folk, som 
Grundtvig slet og ret ser som et kærlighedens folk. ${ }^{39}$ Hos det danske folk er der derfor en særlig mulighed for, at samfundslivet kan udvikle sig i retning af den styreform, som normalfolket har vist vej for.

Man genkender i tankegangen elementer af Grundtvigs version af det opinionsstyrede kongedømme, hvor såvel regenten som undersåtterne er emotionelt motiverede for at respektere hinanden, sådan som det fremgik af "Konge-Haand og Folke-Stemme". Imidlertid er der her i 1814 i højere grad tale om inspiration fra den deuteronomistiske skepsis over for kongeinstitutionen end om inspiration fra de kontraktteoretiske overvejelser, der fra det 17. århundrede og ind i det 19. århundredes begyndelse præger europæisk politisk tænkning. Disse tanker møder man blandt andet i de kontraktteoretiske varianter, hvor folket tildeles magt (Sløk 1962, 251).

\section{Samfundslivet i forstandens og fornuftens epoke}

Grundtvig mener imidlertid, at tanken om den suveræne konge og de debatterende undersåtter forudsætter et bevidstgjort, vågent og - med et nutidigt udtryk - myndiggjort folk. Denne myndiggørelse forestiller han sig - når man følger hans tankemønster - først vil blive virkeliggjort $\mathrm{i}$ historiens tredje og sidste epoke. Denne periode kommer, skønt der i Israel er overlap og organisk sammenhæng med de foregående, efter følelsens periode og domineres af bevidsthedsevnerne forstand og fornuft. Det er i denne sammenhæng, at folkelighedsbegrebet første gang dukker op. Det folkelige er det, der opstår, når styreformen bliver ideel. Grundtvigs skildring af den udvikling, som menneskeheden ville have gennemløbet i paradiset, når her frem til den sidste og afgørende fase, hvor den organiske udvikling kommer til modning og afslutning:

alt som Mennesket fik meer Forstand, da blev det klart, hvorfor det Syn var Sandhed og hvorledes Alting hængde sammen i den ene Kiæde, da adlød Mennesket ei alene fordi han troede og elskede, men tillige efterdi

39 Billedet af det danske folk som et kærlighedens folk er fremtrædende i Europa, Frankrig og Napoleon. En Dansk historisk Betragtning (Grundtvig 1815, 96 f., 99 og 108). Det fremgår imidlertid af omtalen af jafetidernes patriarkalske kongedømmer, at motivet allerede er til stede i nærværende tekst. 
han tydelig erkiendte, at det maatte være saa, da var Slægten, saa at sige, som sin egen Øvrighed, Øvrigheden var da blevet folkelig (251 f.).

Uden syndefaldet ville menneskeslægten have nået dette mål på naturlig vis, uden at særlige foranstaltninger havde været nødvendige. Men efter Evas brøde er alle naturlige sammenhænge brudt op, og nu optræder den folkelige styreform inden for det udvalgte folk, selv om det ikke er nået ind i den tredje periode af udviklingen. Den folkelige styreform kan - i kraft af Guds forsyn - observeres i Israel allerede i tiden før kongedømmet. Karakteristikken af individernes selvstyre som "folkelig" forekommer ganske vist ikke her, men det er det samme fænomen, der er tale om:

Det er da kortelig og rettelig sagt om Israels Vilkaar i Canaan af Begyndelsen som skrevet staar, i de samme Dag [sic!] var ingen Konge i Israel, hver gjorde, hvad Ret var for hans Øine (Domm. B 17) hvert andet Folk, vilde med saadanne Vilkaar i mindre end eet Aarhundrede ødelagt sig selv, og Israel var i den Tilstand, som Nogle mene, fire hundrede, men i det mindste tohundrede Aar og opblomstrede derefter til et mægtigt Folk under samme Lovgivning, hvilket var aldeles uforklarligt, naar vi ei kiendte Herrens Gierninger i Ægypten og i Ørken og i Canaan, de Straffedomme og den Frelsning, som aabenbarede hans Liv og Arms Størke, Hans Nidkiærhed og Miskundhed tillige, og om dette Tidsrum gives megen mærkelig Beskeed i en Bog som er indlemmet blandt de hellige og kaldes Dommernes (266).

Grundtvigs pointe er, at hver enkelt undersåt i Guds enekongedømme i Israel så at sige har internaliseret loven og følger den af egen fri drift. Denne folkelige styreform er som sagt etableret på trods af enhver naturlig udvikling. Israel er nemlig endnu ikke nået frem til eftertankens tidsalder. Det, der overhovedet gør udviklingen mulig, er, at Gud selv gennem sit forsyns styrelse implementerer den vilje til fællesskab, som hører sammen med den folkelige styreform. For Grundtvig hænger dette sammen med, at der i den jødiske historie kan observeres en splittelse mellem det fællesskab, Gud ønsker, og det fællesskab, det hårdnakkede og genstridige folk forlanger. Da folket ikke selv kan, hvad det skal, må Gud handle. Grundtvig mener, at både "Loven" gennem "den fælleds Overdommer" (5 Mos 17,9; Dom 2,16-19) og "Præstesmykket”, dvs. ypperstepræstens 
brystplade med navnene på de tolv stammer (2 Mos 26,15-21), "fordrede en dyb. [sic!] inderlig gudelig Forening, som Folket i Almindelighed ingenlunde ønskede”. I virkeligheden ønskede det jødiske folk på oprørsk vis "et udvortes Samfund" under en konge, således som de øvrige semitiske folk havde det. Men den konge, man derved bad om, var despoten og ikke den konge, hvis virke reguleredes af en lov og af den individuelle, folkelige motivation for at følge loven.

På dette punkt fremgår det indirekte af $V K 1814$, at Grundtvig mener, denne folkelige regeringsform kan - og skal - virkeliggøres i Danmark i hans tid, og at man i samtiden også har bedre mulighed for det, end det jødiske folk ville have haft, hvis ikke Gud havde grebet ind. Nu er "Følelsen langt mere aandelig, Legemet svagere og Fornuften langt mere udviklet" (392 f.), end det tidligere i historien har været tilfældet. Selv om der er meget i den "Forfatning", Gud gav Israel, som Grundtvig og hans medkristne "ikke kan begribe", skal de takke Gud, som "i Menighedens sidste Tider" har undt dem "at erkiende Meget", som var deres fædre "ubegribeligt" (252 f.). I den danske jafetidiske nation ligger med andre ord et stort potentiale for at udvikle et styre, hvor individerne frivilligt og med fornuftgrunde følger loven. Det skyldes blandt andet, at menigheden her har taget imod Kristus. Han er som normalfolkets blomst det menneske, hvori den jødiske folkenatur, må man formode, Grundtvig forestiller sig, når sit ypperste udtryk i fornuftens tidsalder. Så langt når krøniken ikke i sin fremstilling af verdenshistorien, idet den slutter med det jødiske folks babyloniske udlændighed. Alligevel kan man sige, at denne logik er på færde i de mange spredte bemærkninger om jafetiderne og dermed om Danmark. Det trefasede udviklingsforløb er så at sige mønsteret, Grundtvig tager bestik af. Det betyder ikke blot, at Israels historie er et pædagogisk hjælpemiddel, når det gælder den kristne menigheds indsigt i, hvilken menneskelighed den får del i gennem Kristus, men også, at den jødiske stats udvikling til og med Kristus udgør et forbillede for jafetidernes samfundsdannelser.

Efter templets ødelæggelse i år 70 har historiens centrum flyttet sig fra Israel og middelhavsegnene til Europa og gennem middelalderen og nyere tid bevæget sig gradvist længere op mod de nordiske folkeslag. Denne udvikling er "af Gud styret paa forunderlige Maader," men har til trods for modstand og vanskeligheder været i stand til "at naae Maalet" (XXV). Pointen er, at selv om den jødiske nation fortsat er normalfolket, afløses 
den så at sige som udvalgt folk. Derfor er det ikke tilfældigt, at udvælgelsesmotivet få måneder efter verdenskrønikens fremkomst knyttes til det danske folk.

I denne sammenhæng gælder det om at forstå, at Grundtvig ikke blot mener, at paradiset og oldtidens jødedom forløber i tre epoker, der hænger organisk sammen, men at også den helt store verdenshistorie følger dette bøjningsmønster. Hvad mennesket så i oldtiden, udviklede sig i middelalderen og vil blive erkendt som fornuftigt i den sidste tidsalder. I fornuftens tidsalder fik mennesket "meer Forstand" (251), og derfor kunne det forstå lovenes indre, rationelle udformning. Det gælder også nutiden og er baggrunden for, at styreformen kan blive "folkelig". Menneskets ovennævnte tilbøjelighed til at ville "raade sig selv" i fornuftens alder, dvs. på Grundtvigs tid, er således ikke entydigt negativ: Hvis mennesket indser det rette $\mathrm{i}$ Guds vilje med samfundslivet og frivilligt følger den, er dets selvrådighed legitim. Som en følge af syndefaldet er selvrådigheden imidlertid degenereret til oprørsk ulydighed og destruktiv selvstændighedstrang. Kuren mod det ligger i besindelse på det folkelighedsideal, som man finder i oldtidens Israel.

\section{Udvælgelsesmotivet og Danmark i årene efter 1814-krøniken}

Indbildningskraftens dominans i det jødiske digterfolk betyder, at Israel ikke af natur er historisk. Derimod er det danske folk som jafetidisk et følelsens og dermed historiens folk og ifølge syvmenighedstanken bestemt til at åbne historiens lukkede dør. I Grundtvigs kobling af følelse, indre følesans og historisk erindring sporer man den traditionelle, førmoderne karakteristik af historisk viden som knyttet til den sansebaserede erkendelse, dvs. som "die Registrierung von Erfahrung schlechthin" (Seifert 1976, 179). Allerede en måned efter, at $V K 1814$ udkom, gjorde Grundtvig rede for sin tanke om det danske folk som bærer af udviklingen frem gennem middelalderen og ind i eftertankens og erkendelsens alder. 1814-krønikens skildring af samtiden som en historisk tid (385) eller tiden for indsigt i 
historiens gang går således igen i foredragsmanuskriptet til landemodet $\mathrm{i}$ Maribo, Om Udsigterne for Christi Kirke. ${ }^{40}$

Grundtvig gør i manuskriptet rede for, at "Kirken" ved overgangen fra oldtid til middelalder "maatte flytte fra det poetiske Østerland, hvor den hidtil havde sin Bolig, til det kjærlige Vesten og der løfte sig i en ny Skikkelse, skabe en kristelig Følelsens Alder eller Riddertid" (Grundtvig 1814b, 492). "Nu" kan man "frit (...) sige", hævder Grundtvig, at "et saadant" europæisk folk må findes "norden for Elben” (Grundtvig 1814b, 499), og kristendommen vil da blomstre på ny "hos et Folk, (...) hos hvem Følelsen hidindtil har hersket mer end Erkjendelsen, (...) og har af Gud faaet Evner til i sin Tid at vorde det ypperste blandt alle" (Grundtvig 1814b, 499). Dette folk er det danske. "Efter Guds Underfulde Husholdning maa fra os, det ringeste, mest fornedrede blandt Folkene, Lyset og Røsten udgaae til at vejlede de blinde og vække de sovende" (Grundtvig 1814b, 502). Tankegangen er ikke til at tage fejl af. Grundtvig overfører det jødiske folks udvælgelse, lidenhed og forfølgelse på Danmark.

Kort tid efter gennemføres identifikationen af Israel og Danmark eksplicit i Roskilde-Saga til Oplysning af Roskilde-Riim. Skriftet udkom d. 7. oktober med en "Fortale" "undertegnet: Kbhavn 15de Mai 1814" og med et indledende digt, der til slut dateres "1. Pinsedag 1814", dette år d. "29/5" (Johansen I, 97). Fortale og digt synes altså at tale for, at Grundtvig har arbejdet med værket sideløbende med $V K 1814$ og Om Udsigterne for Christi Kirke. I bogen hævder Grundtvig, at "efter Israel var intet Folk i Verden saa øiensynlig Herren kiært som just de Danske, ingensteds var Hans Husholdning for Menneskens Øine den i Canaan saa liig som her" (Grundtvig 1814c, 672). Guds forsyn har ført det danske folk frem til, at det bliver muligt at nå til indsigt i historiens gang og mål.

$\mathrm{Nu}$ kunne man vente, at Grundtvig på baggrund af tanken om det danske folk som et udvalgt folk i de følgende år udfoldede sine politiske overvejelser over teokrati og kongedømme og gjorde rede for sidstnævntes naturgivne forankring hos følelsens og kærlighedens folk i Danmark. Det sker imidlertid ikke. I Udsigt over Verdenskrøniken fornemmelig i det

40 Om Udsigterne for Christi Kirke er udgivet af Grundtvigs efterfølger i Vartov, C.J. Brandt (1817-1889), som i en fodnote skriver, at det vil "overraske mange Læsere" "allerede" her "at møde saa meget af den hele kirkelige og kirkehistoriske Betragtning, som (...) [Grundtvig] fastholdt og udviklede lige til sin Alderdom" (Grundtvig 1814b, 473). 
Lutherske Tidsrum fra 1817 møder man dog på ny tredelingen af styreformer. Med baggrund i "Menneskets Natur og Bestemmelse" (VK 1817, 574) kan man ifølge Grundtvig i "den menneskelige Udvikling" i "hvert enkelt Folks, ligesom den hele Slægts Historie" iagttage "tre store Afsnit". Disse "adskiller sig" "i Statsforfatningen (...) som Hierarchie, Genokratie og Logomachie”, dvs. præstestyre, slægtsstyre og - med en negativ konnotation - hårkløveri. Grundtvig føjer til, at "det er let at indsee hvorledes disse Forfatninger knytte sig naturlig til Indbildningskraftens, Følelsens og Forstandens alder" (VK 1817, 573).

Denne karakteristik af fornuftsalderen som tiden for ubeslutsomt og overdrevent spidsfindigt kværulanteri skyldes, at "Fornuften ligefra Reformationens Dage stræbde efter Enevælde i Mennesket", hvoraf "fulgde en democratisk Retning" (VK 1817, 574). Demokratibegrebet er her negativt ladet. Fremfor at internalisere loven i sig ønsker individerne at råde sig selv i egoistisk forstand. Resultatet er ubeslutsomt kævleri, der ender i anarki. Adjektivet "democratisk" erstatter i 1817 derfor "folkelig" i overensstemmelse med Grundtvigs negative billede af, hvordan "en selvklog Fornuft" (VK 1817, 575) i Frankrig afstedkom revolutionen i 1789. Alligevel er slægtskabet tydeligt derved, at selvrådigheden i $V K 1814$ potentielt både kunne udvikle sig negativt og positivt. Medens den demokratiske udvikling i Frankrig førte til, at "Retten sad i Spydstagen" (VK 1817, 579) førte den, som skildret i $V K 1814$, i det gamle Israel til, at hvert individ frit og uden tvang lød Guds lov. I manuskripterne til Præstø-prædikenerne, der på flere punkter har affinitet til $V K$ 1814, forekommer stikordene "Den præstelige, Den Kongelige den Folkelige Tid” (GPP II, 129), men de udfoldes ikke nærmere.

\section{Afslutning}

Ovenstående tolkning af folkelighedsbegrebet i $V K 1814$ viser en anden betydning og forstålse af folkelighed end de gængse bestemmelser af folkelighed som synonymt med nationalitet. Folkelighed er i 1814-krøniken forbundet med tanken om, at folket i den sidste af de med bevidsthedsevnerne forbundne perioder styrer sig selv. Det sker, fordi hvert enkelt individ indser det rationelle i at følge anordninger og love. Individerne skaber som dele af samfundsorganismens helhed frit og på basis af den enkeltes 
egen indsigt sammenhængskraften i staten. Følgelig kan "folkelig” her kun forstås som en adjektivisk form af "Folk" i betydningen undersåtter eller den gruppe af mennesker, der står i det samme forhold til regenten, dvs. som borgerne i en stat.

Når Grundtvig i VK 1814 anvender adjektivet folkelig på en måde, der forudsætter den enkeltes moralske ansvar og individuelle myndiggørelse, er vi faktisk ikke så langt fra den tankegang, som Korsgaard mener først at kunne finde hos Hal Koch - som en slags dansk repræsentant for den republikanske forståelse af civilsamfundet. Verdenskrønikens politiske overvejelser minder ikke så lidt om medborgertanken, men baggrunden er ikke uden videre den opinionsstyrede kongemagts kontraktteoretiske overvejelser, men dels samtidens syn på jødedommen, dels de gammeltestamentlige tekster, der for både jøder og kristne hører med til den bibelske kanon. Der går ingen lige vej fra Grundtvigs udnyttelse af folkelighedsbegrebet i $V K 1814$ til hans hyppige brug af det i 1830'erne og siden hen, hvor betydningen det nationale dominerer. Men den kontraktteoretiske sammenstilling af "Konge-Haand og Folke-Stemme" i digtet fra 1839 vidner om, at opfattelsen af "Folk" i betydningen undersåtter eller borgere fortsat spiller en rolle for Grundtvig - den betydning, der kommer klart til orde i $V K 1814$.

\section{Forkortelser}

PS I-IX Svend Grundtvig og Georg Christensen (udg.) (1880-1930), N.F.S. Grundtvigs poetiske Skrifter, I-IX, København.

US I-X Holger Begtrup (udg.) (1904-09), Nik. Fred. Sev. Grundtvigs Udvalgte Skrifter, I-X, København.

VK 1812 Grundtvig, N.F.S. (1812), Kort Begreb af Verdens Kronike i Sammenhang, København.

VK 1814 Grundtvig, N.F.S. (1814), Kort Begreb af Verdens Kronike, betragtet i Sammenhang, Første Bind, København.

VK 1817 Grundtvig, N.F.S. (1814), Udsigt over Verdens-Kroniken fornemmelig $i$ det Lutherske Tidsrum, København.

GPP I-II Chr. Thodberg (udg.) (1988), Grundtvigs Prasto-predikener, I-II, København. 
DET JØDISKE FOLK OG FOLKELIGHEDSBEGREBET I I 8 I 4-KRØNIKEN

\section{Litteratur}

\section{Verker af Grundtvig}

Grundtvig, N.F.S. Albeck, Gustav (udg.) (1804/1979), Dag-og Udtogsbøger 1-2, København.

- (1807), Om Religion og Liturgie i US I, 136-173.

- (1810/1956/1959),"Lidet om Jesu Kristi Aabenbaring ved Apostelen Johannes" i Grundtvig-Studier 1956, 64-74, og Grundtvig-Studier 1959, 99-102.

- (1811), "Et Par Ord i Anledning af den gamle Præsts Skrivelse til Fyens og Ribes kaarede Bispe" i Nyeste Skilderie af Kjøbenhavn 8. Aarg. Nr. 65, 13/8 sp. 1023-20 og 17/8 sp. 1039-41.

- (1811),"Sigurd og Brynhild” (Optrin af Nordens Kampeliv), PS II, 245-364.

- (1812), "Foreløbigt Svar til Hr. Doctor Larsen i Anledning af hans Par Ord i Skilderiet No. 83-85” i Nyeste Skilderie af Kjøbenhavn, Nr. 40, 16/5, sp. 625629; nr. 41, 19/5 sp. 641-645; nr. 42, 23/5 sp. 657-661.

- (1813), "Et Par Ord om Gejstlighedens Videnskabelighed eller om kristelig og præstelig Lærdom” i Theologisk Bibliothek, V, 39-58.

- (1813), Til Fadrenelandet om dets Tarv og Fare. Et Ord ved N.F.S. Grundtvig. Prest, i US II, 700-737.

- (1814a), En Liden bibelkrønike for Børn og Menigmand, ved Nik. Fred. Sev. Grundtvig, Prest, København.

- $\quad$ (1814b), “Om Udsigterne for Christi Kirke at læse paa Laalands Landemode i Maribo Domkirke d. 6. Juli 1814" i Dansk Kirke-Tidende 1876, sp. 473-484, 489-504.

- (1814c), Roskilde-Saga til Oplysning af Roskilde-Riim, i US II, 611-615.

- (1815), Europa Frankrig og Napoleon, en dansk historisk Betragtning, København.

- (1829/1875), Krønike-Riim til Børne-Lardom med Indledning og Anmarkninger af Nik. Fred. Sev. Grundtvig, København.

- (1833-43), Haandbog $i$ Verdens-Historien. Efter de bedste Kilder. Et fors $\emptyset g$ af Nik: Fred: Sev: Grundtvig Prest, 1833-1843, i US VI og US VII. 


\section{Kim Arne Pedersen}

\section{Verker af andre forfattere}

Albeck, Gustav (1955), Omkring Grundtvigs Digtsamlinger. Studier i Grundtvigs lyriske Forfatterskab 1808-16, Aarhus-København.

Albertsen, Leif Ludwig (1984), Engelen Mi. En bog om den danske jodefejde, Aarhus.

Andersen, Svend (2010), Macht aus Liebe. Zur Rekonstruktion einer lutherischen politischen Ethik, Berlin/New York.

Auken, Sune (2005), Sagas Spejl. Historie, mytologi og kristendom hos Grundtvig, København.

Bergmann, Werner (2010), "Frühantisemitismus" i Werner Benz (Hrsg.), Handbuch des Antisemitismus. Judenfeindschaft in Geschichte und Gegenwart, III, Berlin.

Blum, Mathias (2009), "Johann David Michaelis" i (Hrsg. Werner Benz) Handbuch des Antisemitismus. Judenfeindschaft in Geschichte und Gegenwart, II, Berlin.

Blumenkranz, Bernhard (1946), Die Judenpredigt Augustins. Ein Beitrag zur Geschichte der jüdisch-christlichen Beziehungen in den ersten Jahrhunderten, Basel.

Brumlik, Micha (2000), Deutscher Geist und Judenhass. Das Verhältnis des philosophischen Idealismus zum Judentum, München.

Buchholz, Friedrich (1813), Moses og Jesus eller om Jodernes og de Christnes intellektuelle og moralske Forhold, København.

Bugge, K.E. (1965), Skolen for Livet. Studier over N.F.S. Grundtvigs padagogiske tanker, København.

Christensen, Chr. Villas (1890), "Den litterære Jødefejde 1813" i Museum. Tidsskrift for Historie og Geografi, København, 129-168.

Christensen, Bent (1998), Omkring Grundtvigs vidskab. En undersogelse af N.F.S. Grundtvigs forhold til den erkendelsesmassige side af det kristeligt nødvendige livsengagement, København.

Davidsen, Jacob (1882), Fra det gamle Kongens Kjøbenhavn, København.

Damsholt, Tine (1994), Troen på folkeviljen. En analyse af en tradition i dansk demokratiopfattelse i de sidste 200 år, Vejle.

Elbek, Jørgen (1973), Grundtvigs atten prøveår, Grenå.

Fichte, J.G. (1806/1845/1846), "Die Grundzüge des gegenwärtigen Zeitalters" i Johann Gottlieb Fichtes sämmtliche Werke, bd. 7, Berlin. 


\section{DET JøDISKE FOLK OG FOLKELIGHEDSBEGREBET I I 8 I4-KRØNIKEN}

- $\quad(1808 / 1845 / 1846)$, "Reden an die Deutsche Nation" i Johann Gottlieb Fichtes sämmtliche Werke, bd. 7, Berlin.

Fortegnelse over den af N.F.S. Grundtvig efterladte Bogsamling, som bortsælges ved offentlig Auction i Klædeboderne Nr. 38, Mandagen d. 29 September 1873, København.

Grell, Helge (1980), Skaberordet og billedordet. Studier over Grundtvigs teologi om ordet, København.

- (1988), Skaberaind og folkeaind. En undersøgelse af Grundtvigs tanker om folk og folkelighed og deres forhold til hans kristendomssyn, Aarhus.

Grønbæk, Villiam (1951), Psykologiske tanker og teorier hos Grundtvig, København.

Grözinger, Karl-Erich (1999), "Erstes Bild: Die Gottesmörder” i Julius H.

Schoeps, Joachim Schlör (Hrsg.) Bilder der Judenfeindschaft. Antisemitismus - Vorurteile und Mythen, Augsburg, 57-66.

Herder, Johann Gottfried (1785/1994), "Briefe, das Studium der Theologie betreffend" i Werke in zehn Bänden, Band 9,1, Frankfurt am Main.

- (1782/1993), "Vom Geist der Ebräischen Poesie: Eine Anleitung für die Liebhaber derselben, und der ältesten Geschichte des menschlichen Geistes" i Werke in zehn Bänden, Band 5, Frankfurt am Main.

Holberg, Ludvig (1742), Jødiske Historie fra Verdens Begyndelse Fortsat til disse Tider, I-II, København.

Holm, Anders (2001), Historie og efterklang: En studie i N.F.S. Grundtvigs tidsskrift Danne-Virke, Odense.

Hortzitz, Nicoline (1999), "Die Sprache der Judenfeindschaft" i H. Schoeps, J. Schlör (Hrsg.), Antisemitismus. Vorurteile und Mythen, München / Zürich, $19-40$.

Høgenhaven, Jesper (2011), "Grundtvig som fortolker af Det Gamle Testamente" i Grundtvig-Studier 2011, 51-80.

Høirup, Henning (1949), Grundtvigs Syn paa Tro og Erkendelse. Modsigelsens Grundsetning som teologisk Aksiom hos Grundtvig, København.

Johansen, Steen (1948-1945), Bibliografi over N.F.S. Grundtvigs Skrifter I-IV, København.

Kjærgaard, Kristoffer (2013), Opfindelsen af jødiskhed, 1813-1849. Semitisk diskurs og produktionen af jødiskhed som andethed, (Ph.d.-afhandling, Roskilde Universitetscenter).

Kongeloven, http://danmarkshistorien.dk/leksikon-og-kilder/kongeloven (Set 1. nov. 2014)

Kornerup, Bjørn (1959), Den danske Kirkes Historie, bd. IV, København. 


\section{Kim Arne Pedersen}

Korsgaard, Ove (1997), Kampen om lyset. Dansk voksenoplysning gennem 500 år, København.

Lausten, Martin Schwarz (2002), Oplysning i kirke og synagoge. Forholdet mellem kristne og jøder $i$ den danske Oplysningstid (1760-1814), København.

- (2012), "Grundtvigs syn på jødedom og jøder i dansk kontekst” i Ove Korsgaard og Michael Schelde (red.), Samfundsbyggeren. Artikler om Grundtvigs samfundstankning, 107-134.

Lundgreen-Nielsen, Flemming (1980), Det handlende ord. Grundtvigs digtning, litteraturkritik og poetik 1798-1819, Bind I-II, København.

- (1992), “Grundtvig og danskhed” i Ole Feldbæk (red.) Dansk Identitetshistorie, III, 9-187.

Luther, Martin (1535-45/1880), Dr. Martin Luther Sämmtliche Schriften / herausgegeben von dr. J. G. Walch. Nachdruck der 2., überarbeiteten Auflage, I-XXIII, I, St. Louis.

Löwenbrück, Anna-Ruth (1995), Judenfeindschaft im Zeitalter der Aufklärung: eine Studie zur Vorgeschichte des modernen Antisemitismus am Beispiel des Göttinger Theologen und Orientalisten Johann David Michaelis (1717-1791), Frankfurt am Main.

Menges, Karl (1996), "Herders Bekehrung der Juden. Ein Beitrag zu vielen Beiträgen in der Geschichte der Emanzipation" i Otto, Regine (Hrsg.) Nationen und Kulturen: Zum 250. Geburtstag Johann Gottfried Herders, Würzburg, 459-470.

Menze, Ernest A. (1994),"Herder's "German Kind of Humanity" and the Jewish Question: Historical context and comtemporary criticism" i Bollacher, Martin (Hrsg.), Johann Gottfried Herder Geschichte und Kultur, Würzburg, 213-228.

- (1996),"Herder and the "Jewish Nation" - Continuity and Supersession" i Otto, Regine (Hrsg.), Nationen und Kulturen: Zum 250. Geburtstag Johann Gottfried Herders, Würzburg, 447-486.

Michelsen, William (1954), Tilblivelsen af Grundtvigs historiesyn. Idehistoriske studier over Grundtvigs verdenskrøniker og deres litterare forudsatninger, København.

Mikkelsen, Inger Lise (1994), "Hyrdeliv og paradisdrøm. Om Grundtvigs syn på hyrder" i Grundtvig-Studier 1994, 122-141.

Mosbech, Holger (1934), Fortolkningen af Johannes' Aabenbaring i fortid og nutid, København.

Møller, Jens (1811), “Om Forskjellen mellem den mosaiske og christelige Religions historiske dokumentation” i Theologisk Bibliothek, bd. I, København, 82-117. 


\section{DET JøDISKE FOLK OG FOLKELIGHEDSBEGREBET I I 8 I4-KRØNIKEN}

- (1812), "Er Pentateuchen et Epos? (Besvaret i en kjort Udvikling og Bedømmelse af de nyeste Hypotheser ved Udgiveren" i Theologisk Bibliothek, bd. III, København, 241-309.

Otzen, Benedikt (1977), Israeliterne i Palestina. Det gamle Israels historie, religion og litteratur, København.

Pedersen, Kim Arne (2013), "Den teologiske modtagelse af Verdenskrøniken 1812” i Grundtvig-Studier 2013, 175-207.

Rosendal, Bent (2006), "Grundtvig forkynder Israels historie: om Verdens Krønike 1814" i Dansk teologisk Tidsskrift 2006, 144-156.

Prenter, Regin (1983), "Grundtvigs treenighedslære” i N.F.S. Grundtvig theolog og kirkelerer udgivet af Udvalget for Konvent for Kirke og Theologi, Christiansfeld, 54-76.

Schoeps, Hans-Joachim (1965), Barocke Juden - Christen -Judenchristen, Bern.

Seip, Jens Arup (1958), “Teorien om det opinionsstyrte enevelde” i Norsk Historisk Tidsskrift 1958, 397-463.

Seifert, Arno (1976), Cognitio Historica. Die Geschichte als Namengeberin der frühneuzeitlichen Empirie. Historische Forschungen, Berlin.

Sløk, Johannes mf. (1962), De europaiske ideers historie, København.

Sølvbjerg, Knud (1982), "Antropologi og poetik i Verdens Krønike 1814” i Grundtvig-Studier 1982, 46-62.

Thodberg, Christian (1998), "Grundtvig og Gammel Testamente - den danske bibel eller Septuaginta?” i Grundtvig-Studier 1998, 61-80.

Toldberg, Helge (1946), Grundtvig som Filolog, København.

- (1950), Grundtvigs Symbolverden, København.

Tudvad, Peter (2010), Stadier på antisemitismens vej. Søren Kierkegaard og Jøderne, København.

Vind, Ole (1999), Grundtvigs historiefilosofi, København.

Weissberg, Liliane (1994), “Juden oder Hebräer? Religiöse und politische Bekehrung bei Herder” i Bollacher, Martin (Hrsg.), Johann Gottfried Herder Geschichte und Kultur, Würzburg, 191-211.

Øhrgaard, Per (1994), "Den tyske blomstring: Sturm und Drang og Goethe-tid" i Verdens Litteratur Historie, bd. 4, København, 161-195.

Aarnes, Sigurd Aa. (1961), Historieskrivning og livssyn hos Grundtvig. En undersøkelse av to-verdenmotivet i verdenskrønikerne, Bergen-Oslo. 